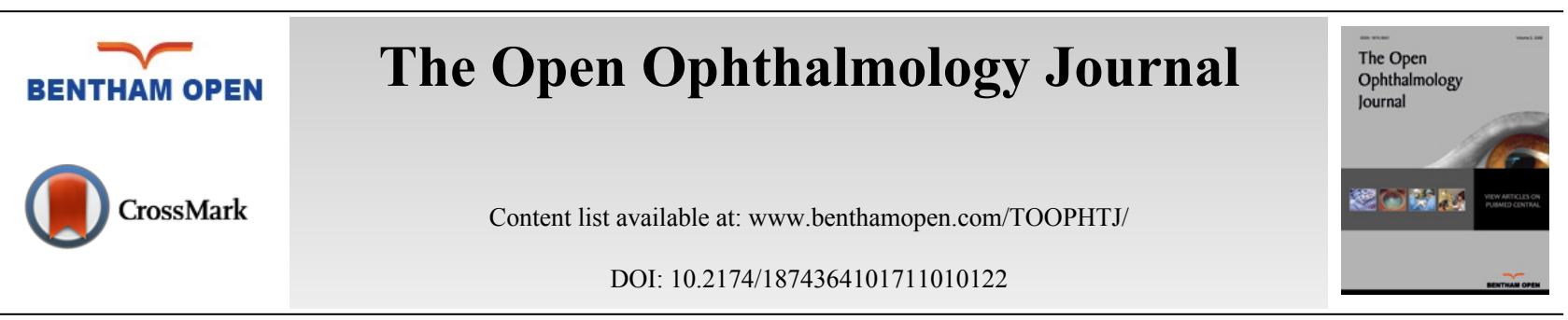

REVIEW ARTICLE

\title{
Many Faces of Renin-angiotensin System - Focus on Eye
}

\author{
Mervi Holappa ${ }^{1}$, Heikki Vapaatalo ${ }^{2}$ and Anu Vaajanen ${ }^{3,4, *}$ \\ ${ }^{I}$ BioMediTech, University of Tampere, Tampere, Finland \\ ${ }^{2}$ Medical Faculty, Department of Pharmacology, University of Helsinki, 00014 Helsinki, Finland \\ ${ }^{3}$ Department of Ophthalmology, Tampere University Hospital, Tampere, Finland \\ ${ }^{4}$ SILK, Department of Ophthalmology, School of Medicine, University of Tampere, Tampere, Finland
}

Received: April 16, 2017

Revised: May 17, 2017

Accepted: May 25, 2017

\begin{abstract}
The renin-angiotensin system (RAS), that is known for its role in the regulation of blood pressure as well as in fluid and electrolyte homeostasis, comprises dozens of angiotensin peptides and peptidases and at least six receptors. Six central components constitute the two main axes of the RAS cascade. Angiotensin (1-7), an angiotensin converting enzyme 2 and Mas receptor axis (ACE2-Ang(1-7)-MasR) counterbalances the harmful effects of the angiotensin II, angiotensin converting enzyme 1 and angiotensin II type 1 receptor axis (ACE1-AngII-AT1R) Whereas systemic RAS is an important factor in blood pressure regulation, tissuespecific regulatory system, responsible for long term regional changes, that has been found in various organs. In other words, RAS is not only endocrine but also complicated autocrine system. The human eye has its own intraocular RAS that is present $e . g$. in the structures involved in aqueous humor dynamics. Local RAS may thus be a target in the development of new anti-glaucomatous drugs. In this review, we first describe the systemic RAS cascade and then the local ocular RAS especially in the anterior part of the eye.
\end{abstract}

Keywords: ACE1, ACE2, Angiotensin II, Angiotensin (1-7), Eye, Glaucoma, Intraocular pressure, Mas receptor, Renin-angiotensin system.

\section{INTRODUCTION}

Glaucoma, known for its destructive effects on the optic nerve axons and retinal ganglion cells, is one of the leading causes of blindness worldwide. In the next three years, approximately 80 million people around the world are predicted to be diagnosed with glaucoma [1]. This number is likely to be even higher due to the fact that glaucoma can be asymptomatic for a long time which makes it difficult to detect until it is severe [2,3]. Glaucoma is a multifactorial optic neuropathy that can be roughly divided into two categories: open-angle glaucoma (POAG) and angle-closure glaucoma, both of which can cause visual field defects and irreversible vision loss [4 - 10].

While many genetic and biological risk factors have been identified, such as age, race and diabetes, the most fundamental reason why a patient is diagnosed with glaucoma is increased intraocular pressure (IOP) $[6,10-13]$. The exact underlying mechanism for glaucoma development is still poorly known which makes it difficult to develop effective therapies for this destructive disease [14,15]. As of today, the only treatment demonstrated to be effective to reduce disease progress is to lower IOP $[16,17]$. That is to say, decrease of IOP by $30 \%$ reduces disease progress $[18$, 19]. In addition to the classical RAS that regulates blood pressure (BP), fluid volume as well as electrolyte balance and is also involved in inflammation, local tissue-specific RA-systems have been described in numerous organs including the human eye [20 - 24]. While the pathological mechanisms at molecular level are not yet well understood, local ocular RAS seems to have a role in ocular pathology and it has been associated to glaucoma and other eye disorders such as diabetic retinopathy (DR), age-related macular degeneration (AMD) and retinopathy of prematurity (ROP) [22, 25]. In this review, we describe the local ocular RAS cascade and concentrate on its potential role in the regulation of

* Address correspondence to this author at the Department of Ophthalmology, Tampere University Hospital, P.O. Box 2000, 33521 Tampere, Finland, Tel +358-3-31164852, E-mail: anu.vaajanen@fimnet.fi 
IOP while keeping the focus on the anterior part of the eye. A comprehensive survey of literature on PubMed was performed to collect the literature and eventually 258 articles were chosen based on their relevance. The following keywords were used and combined to narrow down the literature: IOP (41729), RAS (29132), tissue RAS (6080), angiotensin (116858), angiotensin I (8316), angiotensin II (59230), angiotensin (1-7) (1278), angiotensin (1-9) (73), angiotensin (3-4) (10) angiotensin converting enzyme 1 (238) and -2 (1453), Mas receptor (445), angiotensin receptor (17975), eye disease (5611), glaucoma (59565), diabetic retinopathy (DR) (26740), retinopathy of prematurity (ROP) (6638) and age-related macular degeneration (AMD) (13303).

\section{RENIN-ANGIOTENSIN SYSTEM}

\section{Circulating Ras}

The renin-angiotensin system is one of the oldest and most studied peptide cascades known today. The research concentrating on RAS started, in 1898, in Finland when Robert Tigerstedt and Per Bergman identified a renal BP elevating substance: renin [20, 26, 27]. Over 40 years later, more components of the RAS cascade were identified, one being the angiotensin peptide, first named as angiotonin, that Braun-Menéndez and Page reported to be formed from angiotensinogen by renin, an enzyme originated in the kidney [28 - 30]. 1970 was an important year in the RAS research as its role in BP and fluid balance regulator was understood which led to the development of the first antihypertensive medications such as captopril that blocks the formation of Ang II by inhibiting ACE1 [20, 28]. Later more antihypertensive drugs were designed and developed, one of which was Ang II type 1 receptor blocker (ARB) that blocks the vasoconstrictive effects of Ang II through its main receptor [31].

Multiple peptides, enzymes and receptors have been identified since the first clue of the existence of RAS. One of the important and fairly recent findings was the identification of a new receptor type: MasR whose activities, such as vasodilatation, antifibrosis and antiproliferation, are opposite to those of angiotensin II type 1 receptor (AT1R). This discovery led to the division of RAS into two central axes: ACE1-Ang II-AT1R and ACE2-Ang(1-7)-MasR giving antihypertensive drug development new angles to focus on [32 - 34] as chronic imbalances of these main axes can potentially lead to pathological events of e.g. renal, cardiovascular and central nervous system [35]. In time, RAS has truly evolved from simple linear pathway, having only one known substrate, two proteases, two peptides and one receptor, into a complex cascade consisting of multiple mediators, functionally versatile enzymes and various receptors that are activated by several angiotensin peptides [36 - 40]. Figure 1 shows the full extent of the RAS cascade known today.

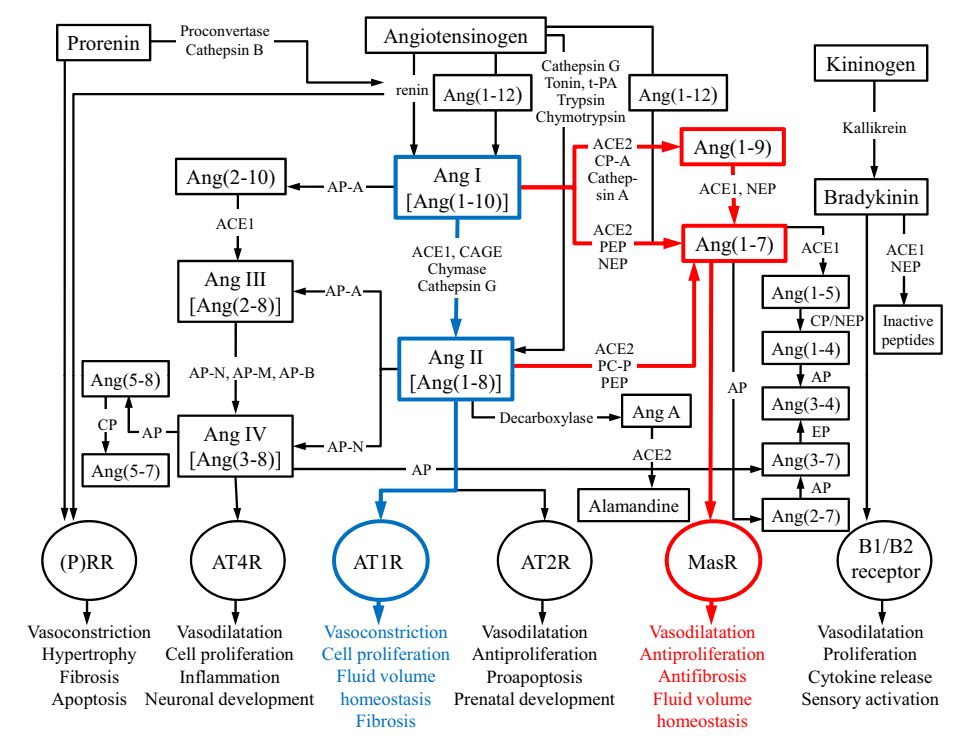

Fig. (1). The renin-angiotensin system. The two main axes of RAS are highlighted with colors. ACE2-Ang(1-7)-MasR axis (red lines) counterbalances the harmful effects of the ACE1-Ang II-AT1R axis (blue lines). ACE1: Angiotensin-converting enzyme 1; ACE2: Angiotensin-converting enzyme related carboxypeptidase; Ang I, II, III, IV: Angiotensin I, II, III, IV; Ang A: Angiotensin A; AT1R, -2R, -4R: Angiotensin II type 1, -2, -4 receptor; AP: Aminopeptidase (-A, -N, -M, -B); B1/B2: Bradykinin receptors; CAGE: Chymostatin-sensitive Ang II generating enzyme; CP: Carboxypeptidase; EP: Endopeptidase; Mas receptor: Ang(1-7) receptor type; NEP: Neprilysin; PEP: Prolyl-endopeptidase; PCP: Prolyl-carboxypeptidase; tPA: Tissue-type plasminogen activator. In angiotensin peptides the numbers in parenthesis refers to the numbers of amino acid residues. The figure is updated from Vaajanen et al. [41]. 
The classical RAS cascade starts with highly specific aspartyl protease renin that cleaves the peptide bond between Leu10 and Val11 at the amino terminus of angiotensinogen (AGT), a 225 amino acids long $\alpha$-glycoprotein, to form angiotensin I (Ang I) [28, 42, 43]. AGT is mainly synthesized and released from liver but other organs such as heart, kidney and adipose tissue can also produce it [44]. Inflammation, insulin and estrogens among other things can stimulate the synthesis of AGT [42]. Renin is mainly synthesized in kidney as an inactive prorenin that is activated by either cathepsin B or proconvertase and secreted from the juxtaglomerular apparatus [28, 42, 43] in response to either decreased arterial BP, decreased sodium levels or increased activity of sympathetic nervous system [45 - 47]. Both renin and prorenin can bind to (pro)renin receptor ((P)RR) and thus mediate vasoconstrictive effects [42, 48].

Ang I, a weak prohormone and vasoconstrictor can be further cleaved to form Ang II. Different enzymes can form Ang II from Ang I: e.g. ACE1, tonin [49], trypsin [50], kallikrein [51], cathepsin G [52] and chymase [53 - 55]. ACE1 is present in many tissues as well as in biological fluids e.g. in plasma [56 - 58]. In order to work, ACE1 needs $\mathrm{Zn}^{2+}$ in complex with activated water molecule in its active site [59] and chloride to improve substrate binding [60]. This main enzyme acting on Ang I, removes two amino acids (His-Leu) from the carboxyl terminus of Ang I to form one of the central peptides of RAS cascade: Ang II. In addition to being an important enzyme in RAS, ACE1 also acts in kallikrain-kinin system [42, 45]. Other enzymes mentioned above are regarded as alternative pathways for Ang II generation [61 - 63] which are important in physiological and pathophysiological conditions [64, 65]. However, these pathways are not discussed further in this review.

In 1940, Ang II an octapeptide also known as Ang (1-8) was first isolated and characterized as a potent vasoconstrictor that raises $\mathrm{BP}$ and regulates e.g. electrolyte balance, vascular tone and thirst $[29,30,43]$. It stimulates the release of aldosterone and vasopressin and exerts its harmful actions, such as vasoconstriction, fibrosis and inflammation via G-protein coupled AT1R [42, 43, 66 - 68]. Furthermore, Ang II can also activate angiotensin II type 2 receptors (AT2R) whose activities are thought to oppose those of AT1R [31, 42, 43]. AT2Rs are regarded as protective receptors as they may elicit vasodilatory, antihypertensive, proapoptotic as well as antiproliferative effects [53, 69] and as they can bind directly to AT1R thus inhibiting signaling through it [31]. ACE inhibitors are used as antihypertensive medications as they oppose the harmful effects of Ang II via AT1R by blocking the conversation of Ang I to Ang II by ACE1 thus elevating the levels of Ang(1-7) [42, 43].

Angiotensin II can then be further cleaved by ACE1 or aminopeptidase A to generate angiotensin III (Ang III) or by aminopeptidase $\mathrm{N}$ to form angiotensin IV (Ang IV) [20, 28, 42, 43]. Ang IV can also be generated from Ang III by aminopeptidases N, M and B [28, 43]. Ang III exerts its vasoconstrictive actions via the same receptors as Ang II (higher affinity to AT2R) whereas Ang IV prefers angiotensin II type 4 receptors (AT4R) which are related to cognitive functions and proliferative effects and which are found e.g. in brain, lung and kidney [20, 70, 71]. Ang IV can also elicit its biological effects, including renal vasodilatation, hypertrophy and regulation of cell growth, through activation of AT1R [72].

Cleavage of one amino acid residue (Phe) from carboxyl terminus of Ang I by ACE2 [73], carboxypeptidase A or cathepsin A [74, 75] generate angiotensin (1-9) (Ang(1-9)) whose main biological functions are to release arachidonic acid, promote nitric oxide formation and increase bradykinin activity [74]. Ang(1-9) may also reduce BP, decrease hypertension [76] and possibly play a role in inhibition of platelet function [77]. The formation of Ang(1-9) is thought to be dependent on ACE2 activity [73, 78] and it has been suggested that Ang(1-9) could mediate its actions by activating the AT2 receptors [76, 79]. ACE2 (42\% sequence identity to ACE1) was first cloned in 2000 and has since been identified in multiple organs such as kidney, heart, brain, liver and lung [42, 73, 80 - 82]. ACE2 has been shown to convert Ang I to Ang(1-9) [73] and most importantly to form Ang(1-7) from Ang II [42, 80, 83 - 85]. This enzyme has zinc metallopeptidase consensus sequence (HEXXH) in its active site and like its homologue ACE2 activity is also regulated by the presence of chloride ions [42]. ACE2 cleaves only one amino acid residue from Ang II thus enhancing Ang(1-7) formation and leaving less substrate to ACE1 to act on [42, 82]. Furthermore, ACE inhibitors used as antihypertensive medications do not block ACE2 activity making this enzyme together with Ang(1-7) and MasR the focus of the research regarding RAS and cardiovascular drug development $[80,86]$.

Ang(1-7) that was first thought to be devoid of biological function can be generated from Ang II by ACE2, prolylendopeptidase and prolyl-carboxypeptidase [20,43, 80, 87] or from Ang(1-9) by ACE1 and NEP [83]. It can also be metabolized directly from Ang I or from prohormone Ang(1-12) bypassing the biosynthesis of Ang II [43, 87]. Moreover, Ang(1-7) can be further metabolized into smaller peptides such as angiotensin (1-5) or angiotensin (2-7) [28]. 
Ang(1-7) is known to have functions opposite to those of Ang II [43]. Although, Ang(1-7) may interact with AT1R and AT2R [76, 79, 84, 86], this peptide elicits its vasodilating and antiproliferatory effects through activation of its main receptor MasR [20, 42, 79, 84]. MasR is a G-protein coupled receptor [88] that was first described as a protooncogene [89]. This receptor has been found e.g. in eye, central nervous system, kidney, heart and brain [88, 90 - 93] and is known to act antagonistically to AT1R [53]. Due to its antiarrhythmogenic, antithrombogenic, growth-inhibitory and vasoconstrictive inhibitory properties, Ang(1-7) is seen as a protective peptide that acts as a counterregulator within RAS [38 - 40]. Interestingly, the association between Ang(1-7) and pathology of multiple diseases such as hypertension $[84,86,87,94-98]$ and diabetic nephropathy $[46,99,100]$ makes this peptide a potential target for drug development.

Interestingly, in addition to ACE2-Ang(1-7)-MasR axis, a newly described member of RAS, angiotensin(3-4) (Ang(3-4)) counteracts the traditional ACE1-Ang II-AT1R pathway both systemically and locally[101]. Ang(3-4) has antihypertensive effects that are mediated via AT2 receptors. This dipeptide is antiproliferative and vasodilating and it inhibits ACE1. Furthermore, it is effective when administered orally, as it permeates intestinal cells relatively easily, lowers Ang II and aldosterone levels in plasma and inhibits ACE1. Ang(3-4) levels are higher in healthy individuals than in hypertensive patients [101]. All in all, it remains open what are the therapeutic possibilities of Ang(3-4) and its potential functions in local RA-systems beyond renal tissue such as in eye.

In addition to previously mentioned angiotensin peptides and enzymes, there are several different peptidases, proteases and small peptides that are part of the RAS cascade but are not discussed in this review. However, all of these enzymes and smaller angiotensin peptides are shown in Fig. (1). In addition, the kallikrein-kinin system that is also shown in Figure 1 and that interacts with RAS is not discussed in detail in this review.

\section{TISSUE RAS}

Even though circulatory RAS has many important roles in human body, various organs have their own tissue specific RA-systems that elicit long term changes and local effects such as growth, proliferation and protein synthesis at organ level [20, 31, 64]. Ganten et al. 1971 were the first researchers to show that RAS is also an organ specific system that has important regulatory roles at tissue level [102]. For example, heart, brain, intestine and even the human eye have their own local RA-systems [6, 31, 43].

Later, local RA-systems were divided into two groups based on the origin of Ang II: extrinsic RAS gets its Ang II from the circulation whereas intrinsic RAS synthesises its own Ang II locally [103]. Although some of the local RAsystems depend on interactions with circulatory RAS to fully operate, in many organs tissue RA-systems prefer to function independently [43]. Indeed local tissue-specific RA-systems can independently produce different components of RAS thus proving that RAS is more than just an endocrine circulatory system and that it regulates more functions than suggested earlier $[6,31,43,64]$.

Local ocular RAS has been found partly in the eye. So far all of the central components of RAS including the components of the two main axes: ACE1-Ang II-AT1R and ACE2-Ang(1-7)-MasR have been identified in different eye structures in various species [6,9]. In the human eye, elements of the two main axes have been identified in retinal as well as in non-retinal ocular structures [6,93, 104]. Tables (1 and 2) summarize the localization of RAS peptides, enzymes and receptors in non-retinal ocular structures of the human eye.

Table 1. Renin-angiotensin system components in bulbar conjunctiva, cornea, trabecular meshwork, aqueous humor, iris, ciliary body and non-pigmented ciliary epithelium, of the human eye.

\begin{tabular}{|c|c|c|c|c|c|c|c|}
\hline RAS component & Bulbar conjunctiva & Cornea & $\begin{array}{l}\text { Trabecular } \\
\text { meshwork }\end{array}$ & Aqueous humor & Iris & Ciliary body/NPE & References \\
\hline Prorenin & $\mathrm{x}$ & $\mathrm{x}$ & & $\mathrm{x}$ & $\mathrm{x}$ & $\mathrm{x}$ & {$[24,105-108]$} \\
\hline Renin & $\mathrm{x}$ & $\mathrm{x}$ & & & $\mathrm{x}$ & $\mathrm{x}$ & {$[105,108]$} \\
\hline AGT & $\mathrm{x}$ & $\mathrm{x}$ & & $\mathrm{x}$ & $x$ & $\mathrm{x}$ & {$[105,109,110]$} \\
\hline ACE1 & $\mathrm{x}$ & $\mathrm{x}$ & $\mathrm{x}$ & $\mathrm{x}$ & $\mathrm{x}$ & $\mathrm{x}$ & {$[104,105,110-116]$} \\
\hline ACE2 & & & & $\mathrm{x}$ & & & \begin{tabular}{|c|}
{$[104]$} \\
\end{tabular} \\
\hline Ang I & & & & $\mathrm{x}$ & $\mathrm{x}$ & $\mathrm{x}$ & {$[117,118]$} \\
\hline Ang II & $\mathrm{x}$ & $\mathrm{x}$ & $x$ & $x$ & $x$ & $\mathrm{x}$ & {$[111,117-119]$} \\
\hline $\operatorname{Ang}(1-7)$ & & & $\mathrm{x}$ & $\mathrm{x}$ & & $\mathrm{x}$ & {$[93,104]$} \\
\hline$(\mathrm{P}) \mathrm{RR}$ & $\mathrm{x}$ & $\mathrm{x}$ & & & $\mathrm{x}$ & $\mathrm{x}$ & {$[105]$} \\
\hline
\end{tabular}


(Table 1) contd.....

\begin{tabular}{|c|c|c|c|c|c|c|c|}
\hline RAS component & Bulbar conjunctiva & Cornea & $\begin{array}{c}\text { Trabecular } \\
\text { meshwork }\end{array}$ & Aqueous humor & Iris & Ciliary body/NPE & References \\
\hline AT, unknown subtype & & & & & $x$ & $\mathrm{x}$ \\
\hline AT1R & $\mathrm{x}$ & $\mathrm{x}$ & & & $\mathrm{x}$ & $\mathrm{x}$ & {$[120,121]$} \\
\hline AT2R & & & & & $\mathrm{x}$ & $\mathrm{x}$ & \\
\hline AT4R & & & & & & & \\
\hline MasR & & $\mathrm{x}$ & $\mathrm{x}$ & & & & \\
\hline
\end{tabular}

Table modified and updated from the table published by Holappa et al. [123]. ACE1, -2: Angiotensin converting enzyme 1, -2; AGT: Angiotensinogen; Ang I, -II: Angiotensin I, -II; Ang(1-7): Angiotensin (1-7); AT1R, -2R, -4R: Angiotensin II type 1, 2, 4 receptor; MasR: Mas receptor; NPE: Non-pigmented ciliary epithelium; (P)RR: (pro)renin receptor; RAS: Renin-angiotensin system.

Table 2. Renin-angiotensin system components in lens, tears and lacrimal gland, vitreous, optic nerve head and sclera of the human eye.

\begin{tabular}{|c|c|c|c|c|c|c|}
\hline RAS component & Lens & Tears/Lacrimal gland & Vitreous & Optic nerve head & Sclera & References \\
\hline Prorenin & & & $\mathrm{x}$ & & $\mathrm{x}$ & {$[24,105,107]$} \\
\hline Renin & & & $\mathrm{x}$ & & $\mathrm{x}$ & {$[24,105]$} \\
\hline AGT & & & $\mathrm{x}$ & $\mathrm{x}$ & $\mathrm{x}$ & {$[105,110]$} \\
\hline ACE1 & & $\mathrm{x}$ & $\mathrm{x}$ & & $\mathrm{x}$ & {$[105,112,114,115,124-127]$} \\
\hline ACE2 & & & & & $\mathrm{x}$ & {$[117]$} \\
\hline Ang I & & & $\mathrm{x}$ & & {$[111,119]$} \\
\hline Ang II & & & $\mathrm{x}$ & & {$[105]$} \\
\hline Ang(1-7) & & & & & $\mathrm{x}$ & {$[119]$} \\
\hline (P)RR & & & & & $\mathrm{x}$ & {$[119]$} \\
\hline AT, unknown subtype & & & & & & \\
\hline AT1R & & & & & & \\
\hline AT2R & & & & & & \\
\hline AT4R & & & & & \\
\hline MasR & & & & & \\
\hline
\end{tabular}

Table modified and updated from the table published by Holappa et al. [123]. ACE1, -2: Angiotensin converting enzyme 1, -2; AGT: Angiotensinogen; Ang I, -II: Angiotensin I, -II; Ang(1-7): Angiotensin (1-7); AT1R, -2R, -4R: Angiotensin II type 1, 2, 4 receptor; MasR: Mas receptor; (P)RR: (pro)renin receptor; RAS: Renin-angiotensin system.

Even though RAS is present in the human eye, its function and significance in ocular pathophysiology is still unknown. Whether angiotensin peptides found in the human eye originate partially from the blood compartment or are synthesized locally has been the topic of the debate [117]. Circulating angiotensins e.g. Ang I and Ang II cannot pass the blood-brain barrier and cannot reach the vitreous fluid when blood-retina barrier in the eye is intact $[24,117,128$, 129]. Moreover, in porcine eyes Ang I and Ang II levels are shown to be 5 to 100 -fold higher than those found from diffusion of blood [117] and in comparison to plasma ACE1 activity are higher in ocular structures of pig and rabbit eyes $[130,131]$. However, intraocular RAS may play a role in the regulation of IOP through its effects on AH dynamics [9, 31]. Ang II has been suggested to increase AH secretion via AT1R [122]. Animal studies as well as studies on different patient groups indicate that systemic antihypertensive RAS-inhibiting medications such as ACE inhibitors [103, 132, 133], ARBs [134 - 136] and renin inhibitors [137], reduce IOP. Moreover, intraocular RAS and its actions have been linked to various eye diseases $[6,138]$.

\section{EYE DISEASES AND LOCAL RAS}

\section{Glaucoma}

Glaucoma is a multifactorial long-term neurodegenerative disorder which can be characterized by the non-apoptotic and apoptotic death of retinal ganglion cells and the loss of retinal nerve fibers all of which lead to loss of visual field $[6,7,9,10]$. The death of retinal ganglion cells leads to increased IOP which is the most important risk factor for the development of glaucoma and the only risk factor amenable to treatment $[15,138,139]$. Increased IOP can lead to ischemia, mechanical impairment, oxidative stress and optic nerve inflammation [140]. However, not every patient with high IOP develops glaucoma nor do all the glaucoma patients have increased IOP [15]. Several other risk factors such as age, family history, diabetes, vascular dysfunction and systemic hypertension have also been linked to glaucoma $[6,9$ 
- 11, 139, 141 - 144]. In addition to genetic and environmental factors, epigenetics also affect the signaling pathways that are held responsible for glaucoma progression $[145,146]$.

IOP is maintained by a homeostatic balance between formation and outflow of AH. In the healthy human eye, the flow of AH against resistance generates an IOP of about $15 \mathrm{mmHg}$ (range 9-21 mmHg) [147 - 149]. Diurnal variation of IOP is about $5 \mathrm{mmHg}$ in healthy subjects. Higher IOP values are normally measured in the morning. Transient postural IOP variations can be even twofold e.g. in yoga practioners during sirsasana, headstand posture [150]. In addition, physical exercise can influence ocular pressure [151, 152]. Typically aerobic exercise reduces IOP due to the better ocular circulation [153] whereas anaerobic exercise elevates IOP due to the transient obstructed ocular circulation [154]. The pressure is needed to maintain the optical and refractive properties of the eye [148, 149, 155]. One of the other fundamental functions of IOP is to maintain the right shape of the eye [148, 155]. The normal AH formation rate $(2.5-2.8 \mu \mathrm{L} / \mathrm{min})$ is lower while sleeping $(1.5 \mu \mathrm{L} / \mathrm{min})$ and can be reduced with ageing and in some systemic diseases such as in diabetes $[9,139,156]$.

$\mathrm{AH}$ is a mixture of different electrolytes, growth factors, proteins, amino acids, cytokines, inorganic and organic solutes [157 - 161]. Circulating AH not only sustains and nourishes non-vascularized eye structures e.g. cornea and lens but it also removes excretory products, transports neurotransmitters and enables mediators and inflammatory cells to circulate in the eye $[9,156]$. Ciliary body epithelial is the site of AH production [147]. Although two passive processes: diffusion and ultrafiltration, that require no cellular activity nor energy [148], also participate on AH production [162], active secretion accounts for $80-90 \%$ of the total $\mathrm{AH}$ formation $[155,156,163]$. Active and selective trans-cellular transport of ions and molecules across the epithelium against concentration gradient requires energy that is generated by hydrolysis of adenosine triphosphate (ATP) by Na $/ \mathrm{K}^{+}$ATPase. $\mathrm{Na}^{+}$and $\mathrm{K}^{+}$activate ATP hydrolysis whereas different molecules such as dinitrophenol and vanadate inhibit $\mathrm{Na}^{+} / \mathrm{K}^{+}$ATPase $[156,164,165]$. Moreover, active transport of $\mathrm{Na}^{+}$ into the posterior chamber causes water flow from the stromal pool into the posterior chamber and two aquaporins (AQP1 and AQP4) have been shown to contribute to $\mathrm{AH}$ formation [166, 167]. Other ions and molecules that are actively transported across the epithelium include $\mathrm{Cl}^{-}, \mathrm{HCO}^{-}$, ascorbic acid and certain amino acids. However, active transport of these components occur to a lesser extent [156, 166, 168 - 170]. After the production and secretion into the posterior chamber, $\mathrm{AH}$ flows between the lens and the iris into the anterior chamber from where it will be disposed $[157,171,172]$.

From the anterior chamber, AH flows through the trabecular meshwork and the canal of Schlemm into the venous blood system [147]. AH can exit the eye through the trabecular, the uveoscleral or the uveolymphatic pathways [139] from which the first is pressure-dependent main route of drainage accounting for $90 \%$ of all AH outflow [9, 139, 173]. Aqueous humor flows through the porous trabecular meshwork passively when appropriate IOP level is reached and AH gets filtered in the process [174]. The actin cytoskeleton and the adhesions of trabecular meshwork cells affect the fluid outflow through the trabecular meshwork [175]. The first route of drainage can also be described as the conventional pathway [176] which rate limiting step is the flow through the inner wall of Schelmm's canal [58]. From Schelmm's canal dozens of collector channels connect with aqueous veins through which AH flows into the circulatory system [177, 178].

In addition to trabecular pathway some AH exit the eye through the uveosscleral route [179]. In comparison to the trabecular pathway the uveoscleral pathway is relatively independent of IOP and undergoes age-dependent changes $[173,179]$. The uveoscleral route of drainage can also be described as the unconventional pathway in which AH drains through the ciliary muscle and exits through the supraciliary space across the anterior/posterior sclera into the choroidal vessels and returns to systemic circulation $[180,181]$. The rate limiting step in uveoscleral pathway is the flow through the ciliary muscle [179].

The third route of drainage that is thought to work as a backup system is located in channels of the ciliary body stroma and intestinal space between ciliary muscle bundles [182]. Other minor outflow pathways via iris vessels, corneal endothelium and anterior vitreous body have also been described [183]. As IOP is the net sum of aqueous humor formation and outflow, anti-glaucomatous treatments aim to lower IOP by either decreasing the rate of AH formation or by increasing AH drainage [184]. Lowering IOP by laser therapy, ocular hypotensive medications or surgical procedures is currently the only therapeutic tool to treat this devastating disease $[6,9,10,28]$.

Some studies have suggested that drugs affecting RAS by blocking its action e.g. ACE inhibitors [132, 133, 185] and ARBs [134, 135] might be potential anti-glaucomatous drugs in the future. Animal studies also support these findings [103, 133, 135 - 137]. ACE inhibitors can affect IOP levels through their actions on AH dynamics. These 
inhibitors can decrease Ang II levels in AH, thus affecting the uveoscleral outflow [118, 186, 187], and slow down AH formation by lowering blood flow in the ciliary body [188] which is the primary site of AH production. ACE inhibitors also act through kallikrein-kinin system. By blocking the breakdown of bradykinin these inhibitors support prostaglandin synthesis which in turn lowers IOP by elevating uveoscleral outflow [189 - 191]. By preventing bradykinin breakdown ACE inhibitors also cause vasodilatation as their actions lead to increased nitric oxide formation by endothelial cells. Both prostaglandins and nitric oxide being vasodilatory also inhibit the synthesis of vasoconstrictive peptide endothelin-1 [192 - 195]. In addition, ARBs have been suggested to elevate uveoscleral outflow and slow down cell death of retinal ganglion cells [195, 196].

RAS components have also been identified in central structures of the eye responsible for AH formation and RAS activity has been reported in cultured human non-pigmented ciliary epithelial cells [6, 120, 122]. Interestingly, Ang(1-7) that acts via MasR and ACE2 activating diminazene aceturate (DIZE) have been reported to have positive effects on glaucoma by decreasing IOP [41, 197, 198]. Indeed, as Ang(1-7) actions are opposite to those of Ang II, this heptapeptide is thought to have beneficial effects on the human body including the eye. Moreover, ACE2 activating compounds are considered as novel pharmacotherapeutic agents [7, 41, 199 - 201].

Whereas Ang(1-7) and ACE2 activation are thought to have positive effects on IOP, Ang II has suggested to have negative effects on the human eye even though some of the results are controversy. Ang II augments cell proliferation in trabecular meshwork and increases collagen synthesis in vivo [187]. Intracamerally administered Ang II also lowers uveoscleral outflow [41] whereas in cats intravenously administered Ang II decreases IOP [202]. Ang II can also act as a secretagogue peptide in non-pigmented ciliary cells [122] as it promotes potassium ion channel activity through $\mathrm{Ca}^{2+}$ signaling [203] and causes higher cytoplasmic sodium concentration by activating $\mathrm{Na}^{+} / \mathrm{H}^{+}$exchange [163]. Imbalances in sodium handling in ciliary and renal tubular epithelium might explain the association between glaucoma and hypertension [204]. On the other hand, defects in autoregulation of the posterior ciliary circulation [205] and microvascular damage affecting the optic nerve blood supply [206] both caused by hypertension could also explain the coexistence of hypertension and glaucoma. Furthermore, hypotensive periods caused by antihypertensive medications can also lead to injured optic nerve fibers [207].

\section{Diabetic Retinopathy}

Diabetic retinopathy (DR) is one of the most leading causes of blindness worldwide and one of the most common microvascular complications of diabetes [208 - 210]. As diabetes becomes more and more common among adults, the incidences of DR are predicted to rise dramatically. Nearly all patients with type 1 diabetes and almost $60 \%$ of patients suffering from type 2 diabetes show some signs of DR later in diabetes [211]. Many factors such as high BP, hyperglycemia, hyperlipidemia, age and oxidative stress play a role in the development of DR [212, 213]. The early state of the disease is described as non-proliferative DR (NPDR) in which microaneurysms are formed due to the weakened retinal blood vessels and blood-retinal barrier breaks down. After the formation of microaneurysms, fluid can leak into retina causing swelling of the macula. Proliferative DR (PDR) is used of more serious and advanced form of DR. In addition to the symptoms seen in NPDR, PDR also manifests blood vessel growth on the surface of the retina and into the vitreous [209, 214, 215].

Studies have shown that RAS, especially Ang II mediated actions through AT1R, is involved in the progression of DR [31, 52, 94, 216 - 218]. Over-expression of Ang II and prorenin as well as vascular endothelial growth factor (VEGF) exists in vitreous humor of individuals suffering from DR [24, 219 - 221]. Ang II promotes angiogenesis and possibly increases the risk of neovascularization and hyperpermeability by increasing the retinal blood vessel permeability [219, 220, 222 - 225]. Furthermore, (P)RR has been linked to the development of DR through its direct effects on expression of angiogenic molecules in retinal cells [226 - 229]. RAS involvement in angiogenesis has promoted research concentrating on the potential therapeutic role of RAS inhibitors in DR [230]. Blocking the RAS cascade can actually slow down the progression of the disease [231 - 233] especially in normotensive patients [234]. In patients with type 1 and type 2 diabetes, a link between decreased blood pressure and reduced DR progression has been described [235, 236]. RAS inhibitors can reduce the risk of DR and possibly affect the progression of the disease in diabetic patients [229]. In addition, ACE2 activation reduces retinal ganglion cell death in hyperglycemic rats [198]. Afterall, more basic research and randomized clinical trials are needed in the future to resolve the exact mechanism of action of RAS compounds. 


\section{Age-related Macular Degeneration}

Age-related macular degeneration (AMD) is a major cause of irreversible vision loss among aged population. This devastating disease is the reason why $8.7 \%$ of people worldwide suffer from blindness [237]. Whereas dry AMD is characterized with the significant loss of photoreceptors leading to the loss of central vision, wet form of AMD causes choroidal neovascularization in which pathologically grown blood vessels penetrate Bruch's membrane and populate retina. $90 \%$ of AMD cases are diagnosed as dry form of AMD. Interestingly, in addition to many risk factors such as old age, smoking, systemic hypertension as well as environmental and genetic factors imbalances in RAS cascade have also been connected to the development of AMD [6, 22, 208, 238 - 241].

Circulating RAS is known for its role as the regulator of BP and defects in RAS cascade can lead to systemic hypertension which in turn raises the risk of developing AMD. Furthermore, Ang II modulates retinal pigment epithelium which suggests that impairment in RAS regulation might affect the function of retinal pigment epithelium as well as the viability of photoreceptors. Ang II affects retinal angiogenesis which in turn suggests that this vasoconstrictive octapeptide might also be involved in choroidal neovascularisation [6, 238]. The activation of two types of RAS receptors: AT1R and (P)RR have also been linked to the development of AMD [242, 243]. Animal studies have shown that losartan an AT1R antagonist [244], ARBs [245], ACE inhibitors [239] and (P)RR inhibitors [243] have positive effects on AMD as these compounds can reduce choroidal neovascularization by suppressing inflammatory agents. As of today, no effective therapies are available for treatment of dry AMD [246]. However, understanding the role of RAS in the development of AMD might help us manage and slow down the progression of this disease [138, 247].

\section{Retinopathy of Prematurity}

Whereas AMD affects elderly people, retinopathy of prematurity (ROP) is an eye disease that only affects premature newborns (born $<32$ weeks) and can lead to permanent vision loss [25, 238]. The main risk factors identified for development of ROP are lower gestational age and low birth weight $(<1.5 \mathrm{~kg})$. In industrialized countries, roughly two-thirds of newborns with birth weight less than $1.25 \mathrm{~kg}$ manifest some signs of ROP. All the risk factors identified for this disease correlate with retinal immaturity at birth [25, 248]. ROP can be characterized as neovascular disease in which retinal neovascularisation leads to several complications such as macula dragging, tractional retinal detachment and vitral haemorrhage [238]. When a premature newborn is brought into a high oxygen environment, the growth of retinal blood vessels that expand from the optic nerve halts. After oxygen conditions are normalized, the inner retinal vasculature fails to regain the normal growth which in turn creates an avascular area and leads to neovascularisation, epiretinal angiogenesis and possibly loss of vision field [249]. Today, laser photocoagulation and intravitreal injections of bevacizumab or pegaptanib are used as therapeutic tools to manage ROP [25, 250, 251].

Interestingly, studies have shown that newborns that are suffering from ROP have had increased levels of serum prorenin [252], ocular renin [253, 254] as well as increased AT1R and AT2R expression [253]. Moreover, studies using animal models with oxygen induced retinopathy have shown that ACE inhibitors and AT1R antagonist treatments during the normal air conditions can reduce pathological angiogenesis in retina [253, 255 - 257]. However, the effects of treating retinal angiogenesis with AT2R antagonist and the possible role of AT2R in retinal vascular pathology are still uncertain [223, 254, 256, 258]. Nath et al. studied RAS involvement in ROP in infant patients (n=44) suffering from ROP as well as in rats with oxygen induced retinopathy. They found significantly higher levels of AGT, ACE1 and Ang II, in vitreous humor of infants suffering from ROP compared to healthy controls. Renin levels were also increased but the difference was found to be statistically not significant. In animal studies up-regulated mRNA expressions for renin, AGT, ACE1 and AT1R were found in retina of the rats suffering from oxygen induced retinopathy. Furthermore, ACE inhibitor (lisinopril) and ARB (telmisartan) were shown to suppress the over-activation induced vascular and retinal functional changes in ROP [25]. However, further research is needed to understand the involvement of RAS in the development and treatment of ROP.

\section{CONCLUSION}

Interestingly, in addition to circulating RAS that is involved in BP regulation and inflammation, local tissue specific RAS has been identified in many organs of the human body including the eye. It has been detected in various parts of the eye even in the structures involved in aqueous humor formation and outflow. These intriguing observations should promote more research concentrating on the possible role of local RAS in aqueous humor dynamics and thus IOP regulation. However, factors such as retinal ganglion cell death due to other reasons than pressure might also be 
involved in glaucoma progression. Identification of the second counter-regulating axis of RAS (ACE2-Ang(1-7)-MasR) has already brought new opportunities into light, and compounds affecting Ang(1-7) synthesis as well as MasR and ACE2 activity offer new and exciting possibilities for ocular pharmacology in the future.

\section{CONSENT FOR PUBLICATION}

Not applicable.

\section{CONFLICT OF INTEREST}

The author confirms that this article content has no conflict of interest.

\section{ACKNOWLEDGEMENTS}

Glaukoomatukisäätiö Lux (AV) and Finska Läkaresällskapet Einar och Karin Stroems Stiftelse (HV). Author contributions: $\mathrm{MH}$ collected the literature, prepared the tables and the figure and wrote the preliminary version of the review article; HV revised the text; and AV revised the text and submitted the article.

\section{REFERENCES}

[1] Quigley HA, Broman AT. The number of people with glaucoma worldwide in 2010 and 2020. Br J Ophthalmol 2006; 90(3): 262-7. [http://dx.doi.org/10.1136/bjo.2005.081224] [PMID: 16488940]

[2] Leite MT, Sakata LM, Medeiros FA. Managing glaucoma in developing countries. Arq Bras Oftalmol 2011; 74(2): 83-4. [http://dx.doi.org/10.1590/S0004-27492011000200001] [PMID: 21779659]

[3] Rotchford AP, Kirwan JF, Muller MA, Johnson GJ, Roux P. Temba glaucoma study: a population-based cross-sectional survey in urban South Africa. Ophthalmology 2003; 110(2): 376-82. [http://dx.doi.org/10.1016/S0161-6420(02)01568-3] [PMID: 12578784]

[4] Friedman DS, Wolfs RC, O’Colmain BJ, et al. Prevalence of open-angle glaucoma among adults in the United States. Arch Ophthalmol 2004; 122(4): 532-8. [http://dx.doi.org/10.1001/archopht.122.4.532] [PMID: 15078671]

[5] Day AC, Baio G, Gazzard G, et al. The prevalence of primary angle closure glaucoma in European derived populations: a systematic review. Br J Ophthalmol 2012; 96(9): 1162-7.

[http://dx.doi.org/10.1136/bjophthalmol-2011-301189] [PMID: 22653314]

[6] Giese MJ, Speth RC. The ocular renin-angiotensin system: a therapeutic target for the treatment of ocular disease. Pharmacol Ther 2014; 142(1): 11-32. [http://dx.doi.org/10.1016/j.pharmthera.2013.11.002] [PMID: 24287313]

[7] Foureaux G, Nogueira JC, Nogueira BS, et al. Antiglaucomatous effects of the activation of intrinsic Angiotensin-converting enzyme 2. Invest Ophthalmol Vis Sci 2013; 54(6): 4296-306. [http://dx.doi.org/10.1167/iovs.12-11427] [PMID: 23702784]

[8] Liu T, Xie L, Ye J, Liu Y, He X. Screening of candidate genes for primary open angle glaucoma. Mol Vis 2012; 18: 2119-26. [PMID: 22876139]

[9] Vaajanen A, Vapaatalo H. Local ocular renin-angiotensin system - a target for glaucoma therapy? Basic Clin Pharmacol Toxicol 2011; 109(4): 217-24.

[http://dx.doi.org/10.1111/j.1742-7843.2011.00729.x] [PMID: 21599836]

[10] Weinreb RN, Khaw PT. Primary open-angle glaucoma. Lancet 2004; 363(9422): 1711-20. [http://dx.doi.org/10.1016/S0140-6736(04)16257-0] [PMID: 15158634]

[11] Tuulonen A, Forsman E, Hagman J, et al. [Update on Current Care Guideline: Glaucoma]. Duodecim 2015; 131 (4): 356-8. [PMID: 26241991]

[12] Caprioli J, Coleman AL. Intraocular pressure fluctuation a risk factor for visual field progression at low intraocular pressures in the advanced glaucoma intervention study. Ophthalmology 2008; 115(7): 1123-1129.e3. [http://dx.doi.org/10.1016/j.ophtha.2007.10.031] [PMID: 18082889]

[13] Kersey T, Clement CI, Bloom P, Cordeiro MF. New trends in glaucoma risk, diagnosis \& management. Indian J Med Res 2013; 137(4): 659-68. [PMID: 23703333]

[14] Weinreb RN, Aung T, Medeiros FA. The pathophysiology and treatment of glaucoma: a review. JAMA 2014; 311 (18): 1901-11. [http://dx.doi.org/10.1001/jama.2014.3192] [PMID: 24825645]

[15] Schmidl D, Schmetterer L, Garhöfer G, Popa-Cherecheanu A. Pharmacotherapy of glaucoma. J Ocul Pharmacol Ther 2015; 31 (2): 63-77. [http://dx.doi.org/10.1089/jop.2014.0067] [PMID: 25587905] 
[16] Hirooka K, Baba T, Fujimura T, Shiraga F. Prevention of visual field defect progression with angiotensin-converting enzyme inhibitor in eyes with normal-tension glaucoma. Am J Ophthalmol 2006; 142(3): 523-5. [http://dx.doi.org/10.1016/j.ajo.2006.04.020] [PMID: 16935614]

[17] Boland MV, Ervin AM, Friedman DS, et al. Comparative effectiveness of treatments for open-angle glaucoma: a systematic review for the U.S. Preventive Services Task Force. Ann Intern Med 2013; 158(4): 271-9. [http://dx.doi.org/10.7326/0003-4819-158-4-201302190-00008] [PMID: 23420235]

[18] Collaborative Normal-Tension Glaucoma Study Group. Comparison of glaucomatous progression between untreated patients with normaltension glaucoma and patients with therapeutically reduced intraocular pressures. Am J Ophthalmol 1998; $126(4)$ : $487-97$. [http://dx.doi.org/10.1016/S0002-9394(98)00223-2] [PMID: 9780093]

[19] The effectiveness of intraocular pressure reduction in the treatment of normal-tension glaucoma. Am J Ophthalmol 1998; $126(4)$ : 498-505. [http://dx.doi.org/10.1016/S0002-9394(98)00272-4] [PMID: 9780094]

[20] Fyhrquist F, Saijonmaa O. Renin-angiotensin system revisited. J Intern Med 2008; 264(3): 224-36. [http://dx.doi.org/10.1111/j.1365-2796.2008.01981.x] [PMID: 18793332]

[21] Wilkinson-Berka JL, Kelly DJ, Rong P, Campbell DJ, Skinner SL. Characterisation of a thymic renin-angiotensin system in the transgenic m(Ren-2)27 rat. Mol Cell Endocrinol 2002; 194(1-2): 201-9. [http://dx.doi.org/10.1016/S0303-7207(02)00217-4] [PMID: 12242043]

[22] Kurihara T, Ozawa Y, Ishida S, Okano H, Tsubota K. Renin-Angiotensin system hyperactivation can induce inflammation and retinal neural dysfunction. Int. J. Inflam. 2012; Available from: https://www.hindawi.com/journals/iji/2012/581695/ 2012. 2012: 581695. [http://dx.doi.org/10.1155/2012/581695]

[23] Igic R, Robinsson C, Erdos E. Angiotensin I converting enzyme activity in the choroid plexus and in the retina. New York: Pergamon Press 1977. [http://dx.doi.org/10.1016/B978-0-08-020933-3.50008-8]

[24] Danser AH, van den Dorpel MA, Deinum J, et al. Renin, prorenin, and immunoreactive renin in vitreous fluid from eyes with and without diabetic retinopathy. J Clin Endocrinol Metab 1989; 68(1): 160-7. [http://dx.doi.org/10.1210/jcem-68-1-160] [PMID: 2642484]

[25] Nath M, Chandra P, Halder N, et al. Involvement of renin-angiotensin system in retinopathy of prematurity - a possible target for therapeutic intervention. PLoS One 2016; 11(12): e0168809. [http://dx.doi.org/10.1371/journal.pone.0168809] [PMID: 28033392]

[26] Robert T, Per B. Niere und Kreislauf. Skand Arch Physiol 1898; 8: 223-71. [http://dx.doi.org/10.1111/j.1748-1716.1898.tb00272.x]

[27] Bader M, Ganten D. Update on tissue renin-angiotensin systems. J Mol Med (Berl) 2008; 86(6): 615-21. [http://dx.doi.org/10.1007/s00109-008-0336-0] [PMID: 18414822]

[28] Vaajanen A, Luhtala S, Oksala O, Vapaatalo H. Does the renin-angiotensin system also regulate intra-ocular pressure? Ann Med 2008; 40(6): 418-27. [http://dx.doi.org/10.1080/07853890802043924] [PMID: 19160528]

[29] Braun-Menendez E, Fasciolo JC, Leloir LF, Muñoz JM. The substance causing renal hypertension. J Physiol 1940; 98(3): 283-98. [http://dx.doi.org/10.1113/jphysiol.1940.sp003850] [PMID: 16995204]

[30] Page IH, Helmer OM. A crystalline pressor substance (angiotonin) resulting from the reaction between renin and renin-activator. J Exp Med 1940; 71(1): 29-42. [http://dx.doi.org/10.1084/jem.71.1.29] [PMID: 19870942]

[31] Paul M, Poyan Mehr A, Kreutz R. Physiology of local renin-angiotensin systems. Physiol Rev 2006; 86(3): $747-803$. [http://dx.doi.org/10.1152/physrev.00036.2005] [PMID: 16816138]

[32] Paulis L, Unger T. Novel therapeutic targets for hypertension. Nat Rev Cardiol 2010; 7(8): 431-41. [http://dx.doi.org/10.1038/nrcardio.2010.85] [PMID: 20567239]

[33] Ferrario CM. ACE2: more of Ang-(1-7) or less Ang II? Curr Opin Nephrol Hypertens 2011; 20(1): 1-6. [http://dx.doi.org/10.1097/MNH.0b013e3283406f57] [PMID: 21045683]

[34] Ferreira AJ, Murça TM, Fraga-Silva RA, Castro CH, Raizada MK, Santos RA. New cardiovascular and pulmonary therapeutic strategies based on the Angiotensin-converting enzyme 2/angiotensin-(1-7)/mas receptor axis. Int. J. Hypertens Available from: https:/www.hindawi.com/journals/ijhy/2012/147825/. 2012. 2012: 147825.

[35] Ferreira AJ, Santos RA, Bradford CN, et al. Therapeutic implications of the vasoprotective axis of the renin-angiotensin system in cardiovascular diseases. Hypertension 2010; 55(2): 207-13.

[http://dx.doi.org/10.1161/HYPERTENSIONAHA.109.140145] [PMID: 20038757]

[36] Lazartigues E. A map and new directions for the (pro)renin receptor in the brain: focus on "A role of the (pro)renin receptor in neuronal cell differentiation". Am J Physiol Regul Integr Comp Physiol 2009; 297(2): R248-9. [http://dx.doi.org/10.1152/ajpregu.00287.2009] [PMID: 19494175]

[37] Santos RA, Ferreira AJ, Simões E Silva AC, Silva AC. Recent advances in the angiotensin-converting enzyme 2-angiotensin(1-7)-Mas axis. 
Exp Physiol 2008; 93(5): 519-27.

[http://dx.doi.org/10.1113/expphysiol.2008.042002] [PMID: 18310257]

[38] Chappell MC. Emerging evidence for a functional angiotensin-converting enzyme 2-angiotensin-(1-7)-MAS receptor axis: more than regulation of blood pressure? Hypertension 2007; 50(4): 596-9. [http://dx.doi.org/10.1161/HYPERTENSIONAHA.106.076216] [PMID: 17785634]

[39] Santos RA, Ferreira AJ. Angiotensin-(1-7) and the renin-angiotensin system. Curr Opin Nephrol Hypertens 2007; 16(2): 122-8. [http://dx.doi.org/10.1097/MNH.0b013e328031f362] [PMID: 17293687]

[40] Simões e Silva AC, Pinheiro SV, Pereira RM, Ferreira AJ, Santos RA. The therapeutic potential of Angiotensin-(1-7) as a novel ReninAngiotensin System mediator. Mini Rev Med Chem 2006; 6(5): 603-9. [http://dx.doi.org/10.2174/138955706776876203] [PMID: 16719835]

[41] Vaajanen A, Vapaatalo H, Kautiainen H, Oksala O. Angiotensin (1-7) reduces intraocular pressure in the normotensive rabbit eye. Invest Ophthalmol Vis Sci 2008; 49(6): 2557-62.

[http://dx.doi.org/10.1167/iovs.07-1399] [PMID: 18223252]

[42] Guang C, Phillips RD, Jiang B, Milani F. Three key proteases--angiotensin-I-converting enzyme (ACE), ACE2 and renin--within and beyond the renin-angiotensin system. Arch Cardiovasc Dis 2012; 105(6-7): 373-85. [http://dx.doi.org/10.1016/j.acvd.2012.02.010] [PMID: 22800722]

[43] Ribeiro-Oliveira A Jr, Nogueira AI, Pereira RM, Boas WW, Dos Santos RA, Simões e Silva AC. The renin-angiotensin system and diabetes: an update. Vasc Health Risk Manag 2008; 4(4): 787-803. [PMID: 19065996]

[44] Weber KT. Aldosterone in congestive heart failure. N Engl J Med 2001; 345(23): 1689-97. [http://dx.doi.org/10.1056/NEJMra000050] [PMID: 11759649]

[45] Masuyer G, Yates CJ, Sturrock ED, Acharya KR. Angiotensin-I converting enzyme (ACE): structure, biological roles, and molecular basis for chloride ion dependence. Biol Chem 2014; 395(10): 1135-49. [http://dx.doi.org/10.1515/hsz-2014-0157] [PMID: 25205727]

[46] Ferrão FM, Lara LS, Lowe J. Renin-angiotensin system in the kidney: What is new? World J Nephrol 2014; 3(3): 64-76. [http://dx.doi.org/10.5527/wjn.v3.i3.64] [PMID: 25332897]

[47] Persson PB. Renin: origin, secretion and synthesis. J Physiol 2003; 552(Pt 3): 667-71. [http://dx.doi.org/10.1113/jphysiol.2003.049890] [PMID: 12949225]

[48] Nguyen G, Delarue F, Burcklé C, Bouzhir L, Giller T, Sraer JD. Pivotal role of the renin/prorenin receptor in angiotensin II production and cellular responses to renin. J Clin Invest 2002; 109(11): 1417-27. [http://dx.doi.org/10.1172/JCI0214276] [PMID: 12045255]

[49] Boucher R, Demassieux S, Garcia R, Genest J. Tonin, angiotensin II system. A review. Circ Res 1977; 41(4)(Suppl. 2): 26-9. [http://dx.doi.org/10.1161/01.RES.41.4.26] [PMID: 20244]

[50] Arakawa K. Serine protease angiotensin II systems. J Hypertens Suppl 1996; 14(5): S3-7. [PMID: 9120682]

[51] Maruta H, Arakawa K. Confirmation of direct angiotensin formation by kallikrein. Biochem J 1983; 213(1): $193-200$. [http://dx.doi.org/10.1042/bj2130193] [PMID: 6555043]

[52] Tonnesen MG, Klempner MS, Austen KF, Wintroub BU. Identification of a human neutrophil angiotension II-generating protease as cathepsin G. J Clin Invest 1982; 69(1): 25-30. [http://dx.doi.org/10.1172/JCI110437] [PMID: 6172448]

[53] Becari C, Oliveira EB, Salgado MC. Alternative pathways for angiotensin II generation in the cardiovascular system. Braz J Med Biol Res 2011; 44(9): 914-9 [http://dx.doi.org/10.1590/S0100-879X2011007500093] [PMID: 21956534]

[54] Urata H, Healy B, Stewart RW, Bumpus FM, Husain A. Angiotensin II-forming pathways in normal and failing human hearts. Circ Res 1990; 66(4): 883-90 [http://dx.doi.org/10.1161/01.RES.66.4.883] [PMID: 2156635]

[55] Urata H, Kinoshita A, Misono KS, Bumpus FM, Husain A. Identification of a highly specific chymase as the major angiotensin II-forming enzyme in the human heart. J Biol Chem 1990; 265(36): 22348-57. [PMID: 2266130]

[56] Parkin ET, Turner AJ, Hooper NM. Secretase-mediated cell surface shedding of the angiotensin-converting enzyme. Protein Pept Lett 2004; 11(5): 423-32. [http://dx.doi.org/10.2174/0929866043406544] [PMID: 15544563]

[57] Hooper NM, Turner AJ. An ACE structure. Nat Struct Biol 2003; 10(3): 155-7. [http://dx.doi.org/10.1038/nsb0303-155] [PMID: 12605218]

[58] Balyasnikova IV, Karran EH, Albrecht RF II, Danilov SM. Epitope-specific antibody-induced cleavage of angiotensin-converting enzyme from the cell surface. Biochem J 2002; 362(Pt 3): 585-95. [http://dx.doi.org/10.1042/bj3620585] [PMID: 11879185] 
[59] Lew RA. The zinc metallopeptidase family: new faces, new functions. Protein Pept Lett 2004; 11(5): $407-14$. [http://dx.doi.org/10.2174/0929866043406481] [PMID: 15544561]

[60] Riordan JF. Angiotensin-I-converting enzyme and its relatives. Genome Biol 2003; 4(8): 225. [http://dx.doi.org/10.1186/gb-2003-4-8-225] [PMID: 12914653]

[61] Campbell DJ. Circulating and tissue angiotensin systems. J Clin Invest 1987; 79(1): 1-6. [http://dx.doi.org/10.1172/JCI112768] [PMID: 3025255]

[62] Balcells E, Meng QC, Johnson WH Jr, Oparil S, Dell'Italia LJ. Angiotensin II formation from ACE and chymase in human and animal hearts: methods and species considerations. Am J Physiol 1997; 273(4 Pt 2): H1769-74. [PMID: 9362242]

[63] Takai S, Sakaguchi M, Jin D, Yamada M, Kirimura K, Miyazaki M. Different angiotensin II-forming pathways in human and rat vascular tissues. Clin Chim Acta 2001; 305(1-2): 191-5. [http://dx.doi.org/10.1016/S0009-8981(01)00379-5] [PMID: 11249939]

[64] Miyazaki M, Takai S. Tissue angiotensin II generating system by angiotensin-converting enzyme and chymase. J Pharmacol Sci 2006; 100(5): 391-7. [http://dx.doi.org/10.1254/jphs.CPJ06008X] [PMID: 16799256]

[65] Resende MM, Mill JG. Alternate angiotensin II-forming pathways and their importance in physiological or physiopathological conditions. Arq Bras Cardiol 2002; 78(4): 425-38. [http://dx.doi.org/10.1590/S0066-782X2002000400012] [PMID: 12011961]

[66] Cheng ZJ, Vapaatalo H, Mervaala E. Angiotensin II and vascular inflammation. Med Sci Monit 2005; 11(6): RA194-205. [PMID: 15917731]

[67] Culman J, Höhle S, Qadri F, et al. Angiotensin as neuromodulator/neurotransmitter in central control of body fluid and electrolyte homeostasis. Clin Exp Hypertens 1995; 17(1-2): 281-93. [http://dx.doi.org/10.3109/10641969509087071] [PMID: 7735275]

[68] Qi GM, Jia LX, Li YL, Li HH, Du J. Adiponectin suppresses angiotensin II-induced inflammation and cardiac fibrosis through activation of macrophage autophagy. Endocrinology 2014; 155(6): 2254-65 [http://dx.doi.org/10.1210/en.2013-2011] [PMID: 24684303]

[69] de Gasparo M, Catt KJ, Inagami T, Wright JW, Unger T. International union of pharmacology. XXIII. The angiotensin II receptors. Pharmacol Rev 2000; 52(3): 415-72. [PMID: 10977869]

[70] Albiston AL, Peck GR, Yeatman HR, Fernando R, Ye S, Chai SY. Therapeutic targeting of insulin-regulated aminopeptidase: heads and tails? Pharmacol Ther 2007; 116(3): 417-27. [http://dx.doi.org/10.1016/j.pharmthera.2007.07.006] [PMID: 17900701]

[71] Chai SY, Fernando R, Peck G, et al. The angiotensin IV/AT4 receptor. Cell Mol Life Sci 2004; 61(21): 2728-37. [http://dx.doi.org/10.1007/s00018-004-4246-1] [PMID: 15549174]

[72] Li XC, Campbell DJ, Ohishi M, Yuan S, Zhuo JL. AT1 receptor-activated signaling mediates angiotensin IV-induced renal cortical vasoconstriction in rats. Am J Physiol Renal Physiol 2006; 290(5): F1024-33. [http://dx.doi.org/10.1152/ajprenal.00221.2005] [PMID: 16380463]

[73] Donoghue M, Hsieh F, Baronas E, et al. A novel angiotensin-converting enzyme-related carboxypeptidase (ACE2) converts angiotensin I to angiotensin 1-9. Circ Res 2000; 87(5): E1-9. [http://dx.doi.org/10.1161/01.RES.87.5.e1] [PMID: 10969042]

[74] Jackman HL, Massad MG, Sekosan M, et al. Angiotensin 1-9 and 1-7 release in human heart: role of cathepsin A. Hypertension 2002; 39(5): 976-81.

[http://dx.doi.org/10.1161/01.HYP.0000017283.67962.02] [PMID: 12019279]

[75] Kokkonen JO, Saarinen J, Kovanen PT. Regulation of local angiotensin II formation in the human heart in the presence of interstitial fluid. Inhibition of chymase by protease inhibitors of interstitial fluid and of angiotensin-converting enzyme by Ang-(1-9) formed by heart carboxypeptidase A-like activity. Circulation 1997; 95(6): 1455-63. [http://dx.doi.org/10.1161/01.CIR.95.6.1455] [PMID: 9118513]

[76] Ocaranza MP, Michea L, Chiong M, Lagos CF, Lavandero S, Jalil JE. Recent insights and therapeutic perspectives of angiotensin-(1-9) in the cardiovascular system. Clin Sci 2014; 127(9): 549-57. [http://dx.doi.org/10.1042/CS20130449] [PMID: 25029123]

[77] Mogielnicki A, Kramkowski K, Chabielska E, Buczko W. Angiotensin 1-9 influences hemodynamics and hemostatics parameters in rats. Pol J Pharmacol 2003; 55: 503-4.

[78] Garabelli PJ, Modrall JG, Penninger JM, Ferrario CM, Chappell MC. Distinct roles for angiotensin-converting enzyme 2 and carboxypeptidase A in the processing of angiotensins within the murine heart. Exp Physiol 2008; 93(5): 613-21. [http://dx.doi.org/10.1113/expphysiol.2007.040246] [PMID: 18356559]

[79] McKinney CA, Fattah C, Loughrey CM, Milligan G, Nicklin SA. Angiotensin-(1-7) and angiotensin-(1-9): function in cardiac and vascular remodelling. Clin Sci 2014; 126(12): 815-27 
[http://dx.doi.org/10.1042/CS20130436] [PMID: 24593683]

[80] Xia H, Lazartigues E. Angiotensin-converting enzyme 2: central regulator for cardiovascular function. Curr Hypertens Rep 2010; 12(3): $170-5$. [http://dx.doi.org/10.1007/s11906-010-0105-7] [PMID: 20424953]

[81] Tipnis SR, Hooper NM, Hyde R, Karran E, Christie G, Turner AJ. A human homolog of angiotensin-converting enzyme. Cloning and functional expression as a captopril-insensitive carboxypeptidase. J Biol Chem 2000; 275(43): 33238-43. [http://dx.doi.org/10.1074/jbc.M002615200] [PMID: 10924499]

[82] Guy JL, Lambert DW, Warner FJ, Hooper NM, Turner AJ. Membrane-associated zinc peptidase families: comparing ACE and ACE2. Biochim Biophys Acta 2005; 1751(1): 2-8. [http://dx.doi.org/10.1016/j.bbapap.2004.10.010] [PMID: 16054014]

[83] Rice GI, Thomas DA, Grant PJ, Turner AJ, Hooper NM. Evaluation of angiotensin-converting enzyme (ACE), its homologue ACE2 and neprilysin in angiotensin peptide metabolism. Biochem J 2004; 383(Pt 1): 45-51. [http://dx.doi.org/10.1042/BJ20040634] [PMID: 15283675]

[84] Santos RA, Ferreira AJ, Verano-Braga T, Bader M. Angiotensin-converting enzyme 2, angiotensin-(1-7) and Mas: new players of the reninangiotensin system. J Endocrinol 2013; 216(2): R1-R17. [http://dx.doi.org/10.1530/JOE-12-0341] [PMID: 23092879]

[85] Vickers C, Hales P, Kaushik V, et al. Hydrolysis of biological peptides by human angiotensin-converting enzyme-related carboxypeptidase. J Biol Chem 2002; 277(17): 14838-43. [http://dx.doi.org/10.1074/jbc.M200581200] [PMID: 11815627]

[86] Dilauro M, Burns KD. Angiotensin-(1-7) and its effects in the kidney. Sci World J 2009; 9: 522-35 [http://dx.doi.org/10.1100/tsw.2009.70] [PMID: 19578709]

[87] Varagic J, Trask AJ, Jessup JA, Chappell MC, Ferrario CM. New angiotensins. J Mol Med (Berl) 2008; 86(6): 663-71. [http://dx.doi.org/10.1007/s00109-008-0340-4] [PMID: 18437333]

[88] Bader M. ACE2, angiotensin-(1-7), and Mas: the other side of the coin. Pflugers Arch 2013; 465(1): 79-85. [http://dx.doi.org/10.1007/s00424-012-1120-0] [PMID: 23463883]

[89] Young D, Waitches G, Birchmeier C, Fasano O, Wigler M. Isolation and characterization of a new cellular oncogene encoding a protein with multiple potential transmembrane domains. Cell 1986; 45(5): 711-9. [http://dx.doi.org/10.1016/0092-8674(86)90785-3] [PMID: 3708691]

[90] Young D, O'Neill K, Jessell T, Wigler M. Characterization of the rat mas oncogene and its high-level expression in the hippocampus and cerebral cortex of rat brain. Proc Natl Acad Sci USA 1988; 85(14): 5339-42. [http://dx.doi.org/10.1073/pnas.85.14.5339] [PMID: 2455902]

[91] Kitaoka T, Sharif M, Hanley MR, Hjelmeland LM. Expression of the MAS proto-oncogene in the retinal pigment epithelium of the rhesus macaque. Curr Eye Res 1994; 13(5): 345-51. [http://dx.doi.org/10.3109/02713689409167298] [PMID: 8055698]

[92] Iwata M, Cowling RT, Gurantz D, et al. Angiotensin-(1-7) binds to specific receptors on cardiac fibroblasts to initiate antifibrotic and antitrophic effects. Am J Physiol Heart Circ Physiol 2005; 289(6): H2356-63. [http://dx.doi.org/10.1152/ajpheart.00317.2005] [PMID: 16024575]

[93] Vaajanen A, Kalesnykas G, Vapaatalo H, Uusitalo H. The expression of Mas-receptor of the renin-angiotensin system in the human eye. Graefes Arch Clin Exp Ophthalmol 2015; 253(7): 1053-9.

[http://dx.doi.org/10.1007/s00417-015-2952-z] [PMID: 25677099]

[94] Ferrario CM, Martell N, Yunis C, et al. Characterization of angiotensin-(1-7) in the urine of normal and essential hypertensive subjects. Am J Hypertens 1998; 11(2): 137-46. [http://dx.doi.org/10.1016/S0895-7061(97)00400-7] [PMID: 9524041]

[95] Luque M, Martin P, Martell N, Fernandez C, Brosnihan KB, Ferrario CM. Effects of captopril related to increased levels of prostacyclin and angiotensin-(1-7) in essential hypertension. J Hypertens 1996; 14(6): 799-805. [http://dx.doi.org/10.1097/00004872-199606000-00017] [PMID: 8793704]

[96] Simões e Silva AC, Diniz JS, Pereira RM, Pinheiro SV, Santos RA. Circulating renin Angiotensin system in childhood chronic renal failure: marked increase of Angiotensin-(1-7) in end-stage renal disease. Pediatr Res 2006; 60(6): 734-9. [http://dx.doi.org/10.1203/01.pdr.0000246100.14061.bc] [PMID: 17065573]

[97] Simões e Silva A. Pathophysiology of arterial hypertension: Insights from pediatric studies. Curr Pediatr Rev 2006; 2: 209-23. [http://dx.doi.org/10.2174/157339606778019684]

[98] Simões E Silva AC, Diniz JS, Regueira Filho A, Santos RA. The renin angiotensin system in childhood hypertension: selective increase of angiotensin-(1-7) in essential hypertension. J Pediatr 2004; 145(1): 93-8. [http://dx.doi.org/10.1016/j.jpeds.2004.03.055] [PMID: 15238914]

[99] Carey RM, Siragy HM. The intrarenal renin-angiotensin system and diabetic nephropathy. Trends Endocrinol Metab 2003; 14(6): 274-81. [http://dx.doi.org/10.1016/S1043-2760(03)00111-5] [PMID: 12890592] 
[100] Tikellis C, Johnston CI, Forbes JM, et al. Characterization of renal angiotensin-converting enzyme 2 in diabetic nephropathy. Hypertension 2003; 41(3): 392-7. [http://dx.doi.org/10.1161/01.HYP.0000060689.38912.CB] [PMID: 12623933]

[101] Dias J, Axelband F, Lara LS, Muzi-Filho H, Vieyra A. Is angiotensin-(3-4) (Val-Tyr), the shortest angiotensin II-derived peptide, opening new vistas on the renin-angiotensin system? J Renin Angiotensin Aldosterone Syst 2017; 18(1): 1470320316689338. [http://dx.doi.org/10.1177/1470320316689338] [PMID: 28097883]

[102] Ganten D, Marquez-Julio A, Granger P, et al. Renin in dog brain. Am J Physiol 1971; 221(6): 1733-7. [PMID: 4330904]

[103] Watkins RW, Baum T, Cedeno K, et al. Topical ocular hypotensive effects of the novel angiotensin converting enzyme inhibitor SCH 33861 in conscious rabbits. J Ocul Pharmacol 1987; 3(4): 295-307. [http://dx.doi.org/10.1089/jop.1987.3.295] [PMID: 3503919]

[104] Holappa M, Valjakka J, Vaajanen A. Angiotensin(1-7) and ACE2, "the hot spots" of renin-angiotensin system, detected in the human aqueous humor. Open Ophthalmol J 2015; 9: 28-32. [http://dx.doi.org/10.2174/1874364101509010028] [PMID: 25926900]

[105] White AJ, Cheruvu SC, Sarris M, et al. Expression of classical components of the renin-angiotensin system in the human eye. J Renin Angiotensin Aldosterone Syst 2015; 16(1): 59-66. [http://dx.doi.org/10.1177/1470320314549791] [PMID: 25287897]

[106] Sramek SJ, Wallow IH, Day RP, Ehrlich EN. Ocular renin-angiotensin: immunohistochemical evidence for the presence of prorenin in eye tissue. Invest Ophthalmol Vis Sci 1988; 29(11): 1749-52. [PMID: 3053530]

[107] Wallow IH, Sramek SJ, Bindley CD, Darjatmoko SR, Gange SJ. Ocular renin angiotensin: EM immunocytochemical localization of prorenin. Curr Eye Res 1993; 12(10): 945-50. [http://dx.doi.org/10.3109/02713689309020401] [PMID: 8293670]

[108] Berka JL, Stubbs AJ, Wang DZ, et al. Renin-containing Müller cells of the retina display endocrine features. Invest Ophthalmol Vis Sci 1995; 36(7): 1450-8. [PMID: 7775123]

[109] Chowdhury UR, Madden BJ, Charlesworth MC, Fautsch MP. Proteome analysis of human aqueous humor. Invest Ophthalmol Vis Sci 2010; 51(10): 4921-31. [http://dx.doi.org/10.1167/iovs.10-5531] [PMID: 20463327]

[110] Sramek SJ, Wallow IH, Tewksbury DA, Brandt CR, Poulsen GL. An ocular renin-angiotensin system. Immunohistochemistry of angiotensinogen. Invest Ophthalmol Vis Sci 1992; 33(5): 1627-32. [PMID: 1559760]

[111] Savaskan E, Löffler KU, Meier F, Müller-Spahn F, Flammer J, Meyer P. Immunohistochemical localization of angiotensin-converting enzyme, angiotensin II and AT1 receptor in human ocular tissues. Ophthalmic Res 2004; 36(6): 312-20. [http://dx.doi.org/10.1159/000081633] [PMID: 15627831]

[112] Vita JB, Anderson JA, Hulem CD, Leopold IH. Angiotensin-converting enzyme activity in ocular fluids. Invest Ophthalmol Vis Sci 1981; 20(2): 255-7.

[PMID: 6257623]

[113] Weinreb RN, Polansky JR, Kramer SG, Baxter JD. Acute effects of dexamethasone on intraocular pressure in glaucoma. Invest Ophthalmol Vis Sci 1985; 26(2): 170-5. [PMID: 4038695]

[114] Aydin E, Demir HD, Sahin S. Plasma and aqueous humor angiotensin-converting enzyme levels in patients with diabetic retinopathy. Curr Eye Res 2010; 35(3): 230-4. [http://dx.doi.org/10.3109/02713680903484242] [PMID: 20373882]

[115] Ferrari-Dileo G, Ryan JW, Rockwood EJ, Davis EB, Anderson DR. Angiotensin-converting enzyme in bovine, feline, and human ocular tissues. Invest Ophthalmol Vis Sci 1988; 29(6): 876-81. [PMID: 2836331]

[116] Igić R, Kojović V. Angiotensin I converting enzyme (kininase II) in ocular tissues. Exp Eye Res 1980; 30(3): $299-303$. [http://dx.doi.org/10.1016/0014-4835(80)90010-X] [PMID: 6249629]

[117] Danser AH, Derkx FH, Admiraal PJ, Deinum J, de Jong PT, Schalekamp MA. Angiotensin levels in the eye. Invest Ophthalmol Vis Sci 1994; 35(3): 1008-18. [PMID: 8125711]

[118] Osusky R, Nussberger J, Amstutz C, Flammer J, Brunner HR. Individual measurements of angiotensin II concentrations in aqueous humor of the eye. Eur J Ophthalmol 1994; 4(4): 228-33. [PMID: 7711476]

[119] Senanayake Pd, Drazba J, Shadrach K, et al. Angiotensin II and its receptor subtypes in the human retina. Invest Ophthalmol Vis Sci 2007; 48(7): 3301-11. 
[http://dx.doi.org/10.1167/iovs.06-1024] [PMID: 17591902]

[120] Lin C, Stone RA, Wax MB. Angiotensin binding sites in rabbit anterior uvea and human ciliary epithelial cells. Invest Ophthalmol Vis Sci 1990; 31(1): 147-52.

[PMID: 2298535]

[121] Lograno MD, Reibaldi A. Receptor-responses in fresh human ciliary muscle. Br J Pharmacol 1986; 87(2): $379-85$. [http://dx.doi.org/10.1111/j.1476-5381.1986.tb10827.x] [PMID: 3006859]

[122] Cullinane AB, Leung PS, Ortego J, Coca-Prados M, Harvey BJ. Renin-angiotensin system expression and secretory function in cultured human ciliary body non-pigmented epithelium. Br J Ophthalmol 2002; 86(6): 676-83. [http://dx.doi.org/10.1136/bjo.86.6.676] [PMID: 12034692]

[123] Holappa M, Vapaatalo H, Vaajanen A. Ocular renin-angiotensin system with special reference in the anterior part of the eye. World J Ophthalmol 2015; 5(3): 110-2. [http://dx.doi.org/10.5318/wjo.v5.i3.110]

[124] Sharma OP, Vita JB. Determination of angiotensin-converting enzyme activity in tears. A noninvasive test for evaluation of ocular sarcoidosis. Arch Ophthalmol 1983; 101(4): 559-61. [http://dx.doi.org/10.1001/archopht.1983.01040010559004] [PMID: 6301411]

[125] Immonen I, Friberg K, Sorsila R, Fyhrquist F. Concentration of angiotensin-converting enzyme in tears of patients with sarcoidosis. Acta Ophthalmol (Copenh) 1987; 65(1): 27-9.

[http://dx.doi.org/10.1111/j.1755-3768.1987.tb08486.x] [PMID: 3033979]

[126] Nakanishi T, Koyama R, Ikeda T, Shimizu A. Catalogue of soluble proteins in the human vitreous humor: comparison between diabetic retinopathy and macular hole. J Chromatogr B Analyt Technol Biomed Life Sci 2002; 776(1): 89-100. [http://dx.doi.org/10.1016/S1570-0232(02)00078-8] [PMID: 12127329]

[127] Ishizaki E, Takai S, Ueki M, et al. Correlation between angiotensin-converting enzyme, vascular endothelial growth factor, and matrix metalloproteinase-9 in the vitreous of eyes with diabetic retinopathy. Am J Ophthalmol 2006; 141(1): 129-34. [http://dx.doi.org/10.1016/j.ajo.2005.08.066] [PMID: 16386986]

[128] Schelling P, Ganten U, Sponer G, Unger T, Ganten D. Components of the renin-angiotensin system in the cerebrospinal fluid of rats and dogs with special consideration of the origin and the fate of angiotensin II. Neuroendocrinology 1980; 31(5): 297-308. [http://dx.doi.org/10.1159/000123092] [PMID: 7003424]

[129] Cunha-Vaz J. The blood-ocular barriers. Surv Ophthalmol 1979; 23(5): 279-96. [http://dx.doi.org/10.1016/0039-6257(79)90158-9] [PMID: 380030]

[130] Ramirez M, Davidson EA, Luttenauer L, et al. The renin-angiotensin system in the rabbit eye. J Ocul Pharmacol Ther 1996; 12 (3): $299-312$. [http://dx.doi.org/10.1089/jop.1996.12.299] [PMID: 8875336]

[131] Geng L, Persson K, Nilsson SF. Angiotensin converting anzyme (ACE) activity in porcine ocular tissue: effects of diet and ACE inhibitors. J Ocul Pharmacol Ther 2003; 19(6): 589-98. [http://dx.doi.org/10.1089/108076803322660503] [PMID: 14733716]

[132] Costagliola C, Di Benedetto R, De Caprio L, Verde R, Mastropasqua L. Effect of oral captopril (SQ 14225) on intraocular pressure in man. Eur J Ophthalmol 1995; 5(1): 19-25. [PMID: 7795397]

[133] Shah GB, Sharma S, Mehta AA, Goyal RK. Oculohypotensive effect of angiotensin-converting enzyme inhibitors in acute and chronic models of glaucoma. J Cardiovasc Pharmacol 2000; 36(2): 169-75. [http://dx.doi.org/10.1097/00005344-200008000-00005] [PMID: 10942157]

[134] Costagliola C, Verolino M, De Rosa ML, Iaccarino G, Ciancaglini M, Mastropasqua L. Effect of oral losartan potassium administration on intraocular pressure in normotensive and glaucomatous human subjects. Exp Eye Res 2000; 71(2): 167-71. [http://dx.doi.org/10.1006/exer.2000.0866] [PMID: 10930321]

[135] Wang RF, Podos SM, Mittag TW, Yokoyoma T. Effect of CS-088, an angiotensin AT1 receptor antagonist, on intraocular pressure in glaucomatous monkey eyes. Exp Eye Res 2005; 80(5): 629-32. [http://dx.doi.org/10.1016/j.exer.2004.11.012] [PMID: 15862169]

[136] Inoue T, Yokoyoma T, Mori Y, et al. The effect of topical CS-088, an angiotensin AT1 receptor antagonist, on intraocular pressure and aqueous humor dynamics in rabbits. Curr Eye Res 2001; 23(2): 133-8. [http://dx.doi.org/10.1076/ceyr.23.2.133.5473] [PMID: 11840352]

[137] Giardina WJ, Kleinert HD, Ebert DM, Wismer CT, Chekal MA, Stein HH. Intraocular pressure lowering effects of the renin inhibitor ABBOTT-64662 diacetate in animals. J Ocul Pharmacol 1990; 6(2): 75-83. [http://dx.doi.org/10.1089/jop.1990.6.75] [PMID: 2203852]

[138] Choudhary R, Kapoor M, Singh A, Bodakhe S. Therapeutic targets of renin-angiotensin system in ocular disorders. J. Curr. Ophthalmol. 2016; pp. 1-10.

[139] Buys ES, Potter LR, Pasquale LR, Ksander BR. Regulation of intraocular pressure by soluble and membrane guanylate cyclases and their role in glaucoma. Front Mol Neurosci 2014; 7: 38. [http://dx.doi.org/10.3389/fnmol.2014.00038] [PMID: 24904270] 
[140] Gauthier AC, Liu J. Neurodegeneration and neuroprotection in glaucoma. Yale J Biol Med 2016; 89(1): 73-9. [PMID: 27505018]

[141] Khawaja AP, Chan MP, Broadway DC, et al. Systemic medication and intraocular pressure in a British population: the EPIC-Norfolk Eye Study. Ophthalmology 2014; 121(8): 1501-7. [http://dx.doi.org/10.1016/j.ophtha.2014.02.009] [PMID: 24702754]

[142] McGwin G Jr, McNeal S, Owsley C, Girkin C, Epstein D, Lee PP. Statins and other cholesterol-lowering medications and the presence of glaucoma. Arch Ophthalmol 2004; 122(6): 822-6. [http://dx.doi.org/10.1001/archopht.122.6.822] [PMID: 15197056]

[143] Budenz DL. A clinician's guide to the assessment and management of nonadherence in glaucoma. Ophthalmology 2009; 116(11)(Suppl.): S43-7.

[http://dx.doi.org/10.1016/j.ophtha.2009.06.022] [PMID: 19837260]

[144] Schwartz GF, Quigley HA. Adherence and persistence with glaucoma therapy. Surv Ophthalmol 2008; 53(Suppl. 1): S57-68. [http://dx.doi.org/10.1016/j.survophthal.2008.08.002] [PMID: 19038625]

[145] Gauthier AC, Liu J. Epigenetics and Signaling Pathways in Glaucoma. Biomed. Res. Int. Available from: https://www.hindawi.com/journals/ bmri/2017/5712341/. 2017. 2017: 5712341 [http://dx.doi.org/10.1155/2017/5712341]

[146] Tham YC, Li X, Wong TY, Quigley HA, Aung T, Cheng CY. Global prevalence of glaucoma and projections of glaucoma burden through 2040: a systematic review and meta-analysis. Ophthalmology 2014; 121(11): 2081-90. [http://dx.doi.org/10.1016/j.ophtha.2014.05.013] [PMID: 24974815]

[147] Janssen SF, Gorgels TG, van der Spek PJ, Jansonius NM, Bergen AA. In silico analysis of the molecular machinery underlying aqueous humor production: potential implications for glaucoma. J Clin Bioinforma 2013; 3(1): 21. [http://dx.doi.org/10.1186/2043-9113-3-21] [PMID: 24165276]

[148] Civan MM, Macknight AD. The ins and outs of aqueous humour secretion. Exp Eye Res 2004; 78(3): 625-31. [http://dx.doi.org/10.1016/j.exer.2003.09.021] [PMID: 15106942]

[149] Brubaker RF. The flow of aqueous humor in the human eye. Trans Am Ophthalmol Soc 1982; 80: $391-474$. [PMID: 6763801]

[150] Baskaran M, Raman K, Ramani KK, Roy J, Vijaya L, Badrinath SS. Intraocular pressure changes and ocular biometry during Sirsasana (headstand posture) in yoga practitioners. Ophthalmology 2006; 113(8): 1327-32. [http://dx.doi.org/10.1016/j.ophtha.2006.02.063] [PMID: 16806478]

[151] Dane S, Koçer I, Demirel H, Uçok K, Tan U. Long-term effects of mild exercise on intraocular pressure in athletes and sedentary subjects. Int J Neurosci 2006; 116(10): 1207-14. [http://dx.doi.org/10.1080/00207450500516461] [PMID: 16923688]

[152] Dane S, Koçer I, Demirel H, Ucok K, Tan U. Effect of acute submaximal exercise on intraocular pressure in athletes and sedentary subjects. Int J Neurosci 2006; 116(10): 1223-30. [http://dx.doi.org/10.1080/00207450500522501] [PMID: 16923690]

[153] Marcus DF, Krupin T, Podos SM, Becker B. The effect of exercise on intraocular pressure. I. Human beings. Invest Ophthalmol 1970; 9(10): 749-52.

[PMID: 5479444]

[154] Vieira GM, Oliveira HB, de Andrade DT, Bottaro M, Ritch R. Intraocular pressure variation during weight lifting. Arch Ophthalmol 2006; 124(9): 1251-4. [http://dx.doi.org/10.1001/archopht.124.9.1251] [PMID: 16966619]

[155] Mark HH. Aqueous humor dynamics in historical perspective. Surv Ophthalmol 2010; 55(1): 89-100. [http://dx.doi.org/10.1016/j.survophthal.2009.06.005] [PMID: 19783023]

[156] Goel M, Picciani RG, Lee RK, Bhattacharya SK. Aqueous humor dynamics: a review. Open Ophthalmol J $2010 ; 4$ : 52-9. [http://dx.doi.org/10.2174/1874364101004010052] [PMID: 21293732]

[157] To CH, Kong CW, Chan CY, Shahidullah M, Do CW. The mechanism of aqueous humour formation. Clin Exp Optom 2002; 85(6): 335-49. [http://dx.doi.org/10.1111/j.1444-0938.2002.tb02384.x] [PMID: 12452784]

[158] Freddo TF. The Glenn A. Fry Award Lecture 1992: aqueous humor proteins: a key for unlocking glaucoma? Optom Vis Sci 1993; 70(4): 263-70. [http://dx.doi.org/10.1097/00006324-199304000-00003] [PMID: 8502454]

[159] McLaren JW, Ziai N, Brubaker RF. A simple three-compartment model of anterior segment kinetics. Exp Eye Res 1993; 56(3): 355-66. [http://dx.doi.org/10.1006/exer.1993.1046] [PMID: 8472791]

[160] Barsotti MF, Bartels SP, Freddo TF, Kamm RD. The source of protein in the aqueous humor of the normal monkey eye. Invest Ophthalmol Vis Sci 1992; 33(3): 581-95. [PMID: 1544784]

[161] Freddo TF, Bartels SP, Barsotti MF, Kamm RD. The source of proteins in the aqueous humor of the normal rabbit. Invest Ophthalmol Vis Sci 
1990; 31(1): 125-37.

[PMID: 2298533]

[162] Millar J, True Gablet B, Kaufman P. Aqueous humor dynamics. A review. Open Optho J 2010; 4: $52-9$.

[163] Hou Y, Delamere NA. Influence of ANG II on cytoplasmic sodium in cultured rabbit nonpigmented ciliary epithelium. Am J Physiol Cell Physiol 2002; 283(2): C552-9. [http://dx.doi.org/10.1152/ajpcell.00459.2001] [PMID: 12107065]

[164] Cousins SW, McCabe MM, Danielpour D, Streilein JW. Identification of transforming growth factor-beta as an immunosuppressive factor in aqueous humor. Invest Ophthalmol Vis Sci 1991; 32(8): 2201-11.

[PMID: 2071334]

[165] Becker B. Vanadate and aqueous humor dynamics. Proctor Lecture. Invest Ophthalmol Vis Sci 1980; 19(10): 1156-65. [PMID: 6106642]

[166] Caprioli J. The ciliary epithelia and aqueous humor. In: Hart WM, Ed. Adler's Physiology of the eye. 9th ed. St. Louis: Mosby-Year book Inc 1992; pp. 118-47.

[167] Yamaguchi Y, Watanabe T, Hirakata A, Hida T. Localization and ontogeny of aquaporin-1 and -4 expression in iris and ciliary epithelial cells in rats. Cell Tissue Res 2006; 325(1): 101-9.

[http://dx.doi.org/10.1007/s00441-005-0122-z] [PMID: 16525835]

[168] Wistrand PJ. Carbonic anhydrase in the anterior uvea of the rabbit. Acta Physiol Scand 1951; 24(2-3): 145-8. [http://dx.doi.org/10.1111/j.1748-1716.1951.tb00833.x] [PMID: 14894256]

[169] Tsukaguchi H, Tokui T, Mackenzie B, et al. A family of mammalian Na+-dependent L-ascorbic acid transporters. Nature 1999; 399(6731): 70-5. [http://dx.doi.org/10.1038/19986] [PMID: 10331392]

[170] Reddy VN. Dynamics of transport systems in the eye. Friedenwald Lecture. Invest Ophthalmol Vis Sci 1979; 18(10): 1000-18. [PMID: 225285]

[171] Fitt AD, Gonzalez G. Fluid mechanics of the human eye: aqueous humour flow in the anterior chamber. Bull Math Biol 2006; 68(1): 53-71. [http://dx.doi.org/10.1007/s11538-005-9015-2] [PMID: 16794921]

[172] Murray DL, Bartels SP. The relationship between aqueous humor flow and anterior chamber protein concentration in rabbits. Invest Ophthalmol Vis Sci 1993; 34(2): 370-6. [PMID: 8440591]

[173] Lütjen-Drecoll E, Gabelt BT, Tian B, Kaufman PL. Outflow of aqueous humor. J Glaucoma 2001; 10(5)(Suppl. 1): S42-4. [http://dx.doi.org/10.1097/00061198-200110001-00016] [PMID: 11890273]

[174] Tamm ER. The trabecular meshwork outflow pathways: structural and functional aspects. Exp Eye Res 2009; 88(4): 648-55. [http://dx.doi.org/10.1016/j.exer.2009.02.007] [PMID: 19239914]

[175] Tan JC, Peters DM, Kaufman PL. Recent developments in understanding the pathophysiology of elevated intraocular pressure. Curr Opin Ophthalmol 2006; 17(2): 168-74. [PMID: 16552252]

[176] Brubaker RF. Measurement of uveoscleral outflow in humans. J Glaucoma 2001; 10(5)(Suppl. 1): S45-8. [http://dx.doi.org/10.1097/00061198-200110001-00017] [PMID: 11890274]

[177] Johnson M. 'What controls aqueous humour outflow resistance?'. Exp Eye Res 2006; 82(4): 545-57. [http://dx.doi.org/10.1016/j.exer.2005.10.011] [PMID: 16386733]

[178] Bill A. Some aspects of aqueous humour drainage. Eye (Lond) 1993; 7(Pt 1): 14-9. [http://dx.doi.org/10.1038/eye.1993.4] [PMID: 8325404]

[179] Alm A, Nilsson SF. Uveoscleral outflow--a review. Exp Eye Res 2009; 88(4): 760-8. [http://dx.doi.org/10.1016/j.exer.2008.12.012] [PMID: 19150349]

[180] Fautsch MP, Johnson DH. Aqueous humor outflow: what do we know? Where will it lead us? Invest Ophthalmol Vis Sci 2006; 47(10): 4181-7. [http://dx.doi.org/10.1167/iovs.06-0830] [PMID: 17003404]

[181] Nilsson SF. The uveoscleral outflow routes. Eye (Lond) 1997; 11(Pt 2): 149-54. [http://dx.doi.org/10.1038/eye.1997.43] [PMID: 9349404]

[182] Yücel YH, Johnston MG, Ly T, et al. Identification of lymphatics in the ciliary body of the human eye: a novel "uveolymphatic" outflow pathway. Exp Eye Res 2009; 89(5): 810-9. [http://dx.doi.org/10.1016/j.exer.2009.08.010] [PMID: 19729007]

[183] Weinreb RN. Uveoscleral outflow: the other outflow pathway. J Glaucoma 2000; 9(5): 343-5. [http://dx.doi.org/10.1097/00061198-200010000-00001] [PMID: 11039734]

[184] Zhang K, Zhang L, Weinreb RN. Ophthalmic drug discovery: novel targets and mechanisms for retinal diseases and glaucoma. Nat Rev Drug Discov 2012; 11(7): 541-59. [http://dx.doi.org/10.1038/nrd3745] [PMID: 22699774] 
[185] Mehta A, Iyer L, Parmar S, Shah G, Goyal R. Oculohypotensive effect of perindopril in acute and chronic models of glaucoma in rabbits. Can J Physiol Pharmacol 2010; 88(5): 595-600. [http://dx.doi.org/10.1139/Y10-026] [PMID: 20555429]

[186] Inoue T, Yokoyoma T, Koike H. The effect of angiotensin II on uveoscleral outflow in rabbits. Curr Eye Res 2001; 23(2): 139-43. [http://dx.doi.org/10.1076/ceyr.23.2.139.5470] [PMID: 11840353]

[187] Shen F, Zhang L, Liu T. [Effects of angiotensin II on the 3H-TdR incorporation and synthesis of collagen in cultured bovine trabecular meshwork cells]. Yan Ke Xue Bao 2001; 17(4): 209-12. [PMID: 12567506]

[188] Reitsamer HA, Kiel JW. Relationship between ciliary blood flow and aqueous production in rabbits. Invest Ophthalmol Vis Sci 2003; 44(9): 3967-71. [http://dx.doi.org/10.1167/iovs.03-0088] [PMID: 12939316]

[189] Lotti VJ, Pawlowski N. Prostaglandins mediate the ocular hypotensive action of the angiotensin converting enzyme inhibitor MK-422 (enalaprilat) in African green monkeys. J Ocul Pharmacol 1990; 6(1): 1-7. [http://dx.doi.org/10.1089/jop.1990.6.1] [PMID: 2163428]

[190] Nilsson SF, Samuelsson M, Bill A, Stjernschantz J. Increased uveoscleral outflow as a possible mechanism of ocular hypotension caused by prostaglandin F2 alpha-1-isopropylester in the cynomolgus monkey. Exp Eye Res 1989; 48(5): 707-16. [http://dx.doi.org/10.1016/0014-4835(89)90011-0] [PMID: 2737263]

[191] Weinreb RN, Toris CB, Gabelt BT, Lindsey JD, Kaufman PL. Effects of prostaglandins on the aqueous humor outflow pathways. Surv Ophthalmol 2002; 47(Suppl. 1): S53-64

[http://dx.doi.org/10.1016/S0039-6257(02)00306-5] [PMID: 12204701]

[192] Momose N, Fukuo K, Morimoto S, Ogihara T. Captopril inhibits endothelin-1 secretion from endothelial cells through bradykinin. Hypertension 1993; 21(6 Pt 2): 921-4. [http://dx.doi.org/10.1161/01.HYP.21.6.921] [PMID: 8389325]

[193] Haefliger IO, Flammer J, Lüscher TF. Nitric oxide and endothelin-1 are important regulators of human ophthalmic artery. Invest Ophthalmol Vis Sci 1992; 33(7): 2340-3. [PMID: 1607246]

[194] Yao K, Tschudi M, Flammer J, Lüscher TF. Endothelium-dependent regulation of vascular tone of the porcine ophthalmic artery. Invest Ophthalmol Vis Sci 1991; 32(6): 1791-8.

[PMID: 2032802]

[195] Quigley HA, Pitha IF, Welsbie DS, et al. Losartan treatment protects retinal ganglion cells and alters scleral remodeling in experimental glaucoma. PLoS One 2015; 10(10): e0141137. [http://dx.doi.org/10.1371/journal.pone.0141137] [PMID: 26505191]

[196] Yang H, Hirooka K, Fukuda K, Shiraga F. Neuroprotective effects of angiotensin II type 1 receptor blocker in a rat model of chronic glaucoma. Invest Ophthalmol Vis Sci 2009; 50(12): 5800-4. [http://dx.doi.org/10.1167/iovs.09-3678] [PMID: 19608537]

[197] Sharif NA. Novel potential treatment modalities for ocular hypertension: focus on angiotensin and bradykinin system axes. J Ocul Pharmacol Ther $2015 ; 31(3): 131-45$. [http://dx.doi.org/10.1089/jop.2014.0114] [PMID: 25599263]

[198] Foureaux G, Nogueira BS, Coutinho DC, Raizada MK, Nogueira JC, Ferreira AJ. Activation of endogenous angiotensin converting enzyme 2 prevents early injuries induced by hyperglycemia in rat retina. Braz J Med Biol Res 2015; 48(12): 1109-14. [http://dx.doi.org/10.1590/1414-431X20154583] [PMID: 26421871]

[199] Solinski HJ, Gudermann T, Breit A. Pharmacology and signaling of MAS-related G protein-coupled receptors. Pharmacol Rev 2014; 66(3): 570-97. [http://dx.doi.org/10.1124/pr.113.008425] [PMID: 24867890]

[200] Luhtala S, Vaajanen A, Oksala O, Valjakka J, Vapaatalo H. Activities of angiotensin-converting enzymes ACE1 and ACE2 and inhibition by bioactive peptides in porcine ocular tissues. J Ocul Pharmacol Ther 2009; 25(1): 23-8. [http://dx.doi.org/10.1089/jop.2008.0081] [PMID: 19232015]

[201] Santos RA, Simoes e Silva AC, Maric C, et al. Angiotensin-(1-7) is an endogenous ligand for the G protein-coupled receptor Mas. Proc Natl Acad Sci USA 2003; 100(14): 8258-63. [http://dx.doi.org/10.1073/pnas.1432869100] [PMID: 12829792]

[202] Macri FJ. The action of angiotensin on intraocular pressure. Arch Ophthalmol 1965; 73: 528-39. [http://dx.doi.org/10.1001/archopht.1965.00970030530016] [PMID: 14270142]

[203] Capponi AM, Lew PD, Jornot L, Vallotton MB. Correlation between cytosolic free Ca2+ and aldosterone production in bovine adrenal glomerulosa cells. Evidence for a difference in the mode of action of angiotensin II and potassium. J Biol Chem 1984; 259(14): 8863-9. [PMID: 6746627]

[204] Langman MJ, Lancashire RJ, Cheng KK, Stewart PM. Systemic hypertension and glaucoma: mechanisms in common and co-occurrence. Br J Ophthalmol 2005; 89(8): 960-3. 
[http://dx.doi.org/10.1136/bjo.2004.053397] [PMID: 16024843]

[205] Grunwald JE, Riva CE, Stone RA, Keates EU, Petrig BL. Retinal autoregulation in open-angle glaucoma. Ophthalmology 1984; 91(12): 1690-4.

[http://dx.doi.org/10.1016/S0161-6420(84)34091-X] [PMID: 6521997]

[206] Piltz-seymour JR, Grunwald JE, Hariprasad SM, Dupont J. Optic nerve blood flow is diminished in eyes of primary open-angle glaucoma suspects. Am J Ophthalmol 2001; 132(1): 63-9. [http://dx.doi.org/10.1016/S0002-9394(01)00871-6] [PMID: 11438055]

[207] Hayreh SS, Zimmerman MB, Podhajsky P, Alward WL. Nocturnal arterial hypotension and its role in optic nerve head and ocular ischemic disorders. Am J Ophthalmol 1994; 117(5): 603-24 [http://dx.doi.org/10.1016/S0002-9394(14)70067-4] [PMID: 8172267]

[208] Marin Garcia PJ, Marin-Castaño ME. Angiotensin II-related hypertension and eye diseases. World J Cardiol 2014; 6(9): 968-84. [http://dx.doi.org/10.4330/wjc.v6.i9.968] [PMID: 25276298]

[209] Frank RN. Diabetic retinopathy. N Engl J Med 2004; 350(1): 48-58. [http://dx.doi.org/10.1056/NEJMra021678] [PMID: 14702427]

[210] Harindhanavudhi T, Mauer M, Klein R, Zinman B, Sinaiko A, Caramori ML. Benefits of Renin-Angiotensin blockade on retinopathy in type 1 diabetes vary with glycemic control. Diabetes Care 2011; 34(8): 1838-42. [http://dx.doi.org/10.2337/dc11-0476] [PMID: 21715517]

[211] Bolinger MT, Antonetti DA. Moving past anti-VEGF: novel therapies for treating diabetic retinopathy. Int J Mol Sci 2016; 17(9): E1498. [http://dx.doi.org/10.3390/ijms17091498] [PMID: 27618014]

[212] Tarr JM, Kaul K, Chopra M, Kohner EM, Chibber R. Pathophysiology of diabetic retinopathy 2013. [http://dx.doi.org/10.1155/2013/343560]

[213] Sjølie AK, Dodson P, Hobbs FR. Does renin-angiotensin system blockade have a role in preventing diabetic retinopathy? A clinical review. Int J Clin Pract 2011; 65(2): 148-53. [http://dx.doi.org/10.1111/j.1742-1241.2010.02552.x] [PMID: 21235695]

[214] Wilkinson CP, Ferris FL III, Klein RE, et al. Proposed international clinical diabetic retinopathy and diabetic macular edema disease severity scales. Ophthalmology 2003; 110(9): 1677-82

[http://dx.doi.org/10.1016/S0161-6420(03)00475-5] [PMID: 13129861]

[215] Ivanova T, Jalil A, Antoniou Y, Bishop PN, Vallejo-Garcia JL, Patton N. Vitrectomy for primary symptomatic vitreous opacities: an evidence-based review. Eye (Lond) 2016; 30(5): 645-55. [http://dx.doi.org/10.1038/eye.2016.30] [PMID: 26939559]

[216] Clermont A, Bursell SE, Feener EP. Role of the angiotensin II type 1 receptor in the pathogenesis of diabetic retinopathy: effects of blood pressure control and beyond. J Hypertens Suppl 2006; 24(1): S73-80. [http://dx.doi.org/10.1097/01.hjh.0000220410.69116.f8] [PMID: 16601577]

[217] Mauer M, Zinman B, Gardiner R, et al. Renal and retinal effects of enalapril and losartan in type 1 diabetes. N Engl J Med 2009; 361(1): $40-51$. [http://dx.doi.org/10.1056/NEJMoa0808400] [PMID: 19571282]

[218] Wilkinson-Berka JL, Tan G, Jaworski K, Ninkovic S. Valsartan but not atenolol improves vascular pathology in diabetic Ren-2 rat retina. Am J Hypertens 2007; 20(4): 423-30. [http://dx.doi.org/10.1016/j.amjhyper.2006.09.018] [PMID: 17386351]

[219] Funatsu H, Yamashita H, Nakanishi Y, Hori S. Angiotensin II and vascular endothelial growth factor in the vitreous fluid of patients with proliferative diabetic retinopathy. Br J Ophthalmol 2002; 86(3): 311-5. [http://dx.doi.org/10.1136/bjo.86.3.311] [PMID: 11864890]

[220] Funatsu H, Yamashita H, Ikeda T, Nakanishi Y, Kitano S, Hori S. Angiotensin II and vascular endothelial growth factor in the vitreous fluid of patients with diabetic macular edema and other retinal disorders. Am J Ophthalmol 2002; 133(4): 537-43. [http://dx.doi.org/10.1016/S0002-9394(02)01323-5] [PMID: 11931788]

[221] Schiffman R, Fisher L, Nussbaum J, Edwards P, Scicli G. Prorenin and renin levels in the vitreous of human eyes with and without proliferative diabetic retinopathy. Invest Ophthalmol Vis Sci 1992; 33: 1362.

[222] Nagisa Y, Shintani A, Nakagawa S. The angiotensin II receptor antagonist candesartan cilexetil (TCV-116) ameliorates retinal disorders in rats. Diabetologia 2001; 44(7): 883-8 [http://dx.doi.org/10.1007/s001250100556] [PMID: 11508274]

[223] Otani A, Takagi H, Suzuma K, Honda Y. Angiotensin II potentiates vascular endothelial growth factor-induced angiogenic activity in retinal microcapillary endothelial cells. Circ Res 1998; 82(5): 619-28. [http://dx.doi.org/10.1161/01.RES.82.5.619] [PMID: 9529167]

[224] Fernandez LA, Twickler J, Mead A. Neovascularization produced by angiotensin II. J Lab Clin Med 1985; 105(2): 141-5. [PMID: 2579174]

[225] Aiello LP, Bursell SE, Clermont A, et al. Vascular endothelial growth factor-induced retinal permeability is mediated by protein kinase C in vivo and suppressed by an orally effective beta-isoform-selective inhibitor. Diabetes 1997; 46(9): 1473-80. 
[http://dx.doi.org/10.2337/diab.46.9.1473] [PMID: 9287049]

[226] Haque R, Hur EH, Farrell AN, Iuvone PM, Howell JC. MicroRNA-152 represses VEGF and TGF $\beta 1$ expressions through post-transcriptional inhibition of (Pro)renin receptor in human retinal endothelial cells. Mol Vis 2015; 21: 224-35. [PMID: 25802486]

[227] Kanda A, Ishida S. The vitreous renin-angiotensin system is mediated by soluble (pro)renin receptor in diabetic retinopathy: A new implication of the receptor-associated prorenin system. Taiwan J Ophthalmol 2013; 3: 51-3. [http://dx.doi.org/10.1016/j.tjo.2013.04.004]

[228] Kanda A, Noda K, Saito W, Ishida S. (Pro) renin receptor is associated with angiogenic activity in proliferative diabetic retinopathy. Diabetologia 2012; 55(11): 3104-13. [http://dx.doi.org/10.1007/s00125-012-2702-2] [PMID: 22930161]

[229] Satofuka S, Ichihara A, Nagai N, et al. (Pro)renin receptor-mediated signal transduction and tissue renin-angiotensin system contribute to diabetes-induced retinal inflammation. Diabetes 2009; 58(7): 1625-33. [http://dx.doi.org/10.2337/db08-0254] [PMID: 19389828]

[230] Vincent F, Bonnin P, Clemessy M, et al. Angiotensinogen delays angiogenesis and tumor growth of hepatocarcinoma in transgenic mice. Cancer Res 2009; 69(7): 2853-60. [http://dx.doi.org/10.1158/0008-5472.CAN-08-2484] [PMID: 19318581]

[231] Estacio RO, Jeffers BW, Hiatt WR, Biggerstaff SL, Gifford N, Schrier RW. The effect of nisoldipine as compared with enalapril on cardiovascular outcomes in patients with non-insulin-dependent diabetes and hypertension. N Engl J Med 1998; $338(10)$ : 645-52. [http://dx.doi.org/10.1056/NEJM199803053381003] [PMID: 9486993]

[232] Lewis EJ, Hunsicker LG, Bain RP, Rohde RD. The effect of angiotensin-converting-enzyme inhibition on diabetic nephropathy. N Engl J Med 1993; 329(20): 1456-62.

[http://dx.doi.org/10.1056/NEJM199311113292004] [PMID: 8413456]

[233] Jonas JB, Hayreh SS, Martus P. Influence of arterial hypertension and diet-induced atherosclerosis on macular drusen. Graefes Arch Clin Exp Ophthalmol 2003; 241(2): 125-34 [http://dx.doi.org/10.1007/s00417-002-0615-3] [PMID: 12605267]

[234] Wang B, Wang F, Zhang Y, et al. Effects of RAS inhibitors on diabetic retinopathy: a systematic review and meta-analysis. Lancet Diabetes Endocrinol 2015; 3(4): 263-74. [http://dx.doi.org/10.1016/S2213-8587(14)70256-6] [PMID: 25660574]

[235] Tight blood pressure control and risk of macrovascular and microvascular complications in type 2 diabetes: UKPDS 38. BMJ 1998; 317(7160): 703-13.

[http://dx.doi.org/10.1136/bmj.317.7160.703] [PMID: 9732337]

[236] Chaturvedi N, Sjolie AK, Stephenson JM, et al. Effect of lisinopril on progression of retinopathy in normotensive people with type 1 diabetes. The EUCLID Study Group. EURODIAB Controlled Trial of Lisinopril in Insulin-Dependent Diabetes Mellitus. Lancet 1998; 351(9095): 28-31.

[http://dx.doi.org/10.1016/S0140-6736(97)06209-0] [PMID: 9433426]

[237] Satofuka S, Ichihara A, Nagai N, et al. Role of nonproteolytically activated prorenin in pathologic, but not physiologic, retinal neovascularization. Invest Ophthalmol Vis Sci 2007; 48(1): 422-9. [http://dx.doi.org/10.1167/iovs.06-0534] [PMID: 17197563]

[238] Fletcher EL, Phipps JA, Ward MM, Vessey KA, Wilkinson-Berka JL. The renin-angiotensin system in retinal health and disease: Its influence on neurons, glia and the vasculature. Prog Retin Eye Res 2010; 29(4): 284-311. [http://dx.doi.org/10.1016/j.preteyeres.2010.03.003] [PMID: 20380890]

[239] Nagai N, Oike Y, Izumi-Nagai K, et al. Suppression of choroidal neovascularization by inhibiting angiotensin-converting enzyme: minimal role of bradykinin. Invest Ophthalmol Vis Sci 2007; 48(5): 2321-6. [http://dx.doi.org/10.1167/iovs.06-1296] [PMID: 17460297]

[240] Praddaude F, Cousins SW, Pêcher C, Marin-Castaño ME. Angiotensin II-induced hypertension regulates AT1 receptor subtypes and extracellular matrix turnover in mouse retinal pigment epithelium. Exp Eye Res 2009; 89(1): 109-18. [http://dx.doi.org/10.1016/j.exer.2009.02.020] [PMID: 19281810]

[241] Striker GE, Praddaude F, Alcazar O, Cousins SW, Marin-Castaño ME. Regulation of angiotensin II receptors and extracellular matrix turnover in human retinal pigment epithelium: role of angiotensin II. Am J Physiol Cell Physiol 2008; 295(6): C1633-46. [http://dx.doi.org/10.1152/ajpcell.00092.2008] [PMID: 18923060]

[242] Ishida S. [Lifestyle-related diseases and anti-aging ophthalmology: suppression of retinal and choroidal pathologies by inhibiting reninangiotensin system and inflammation]. Nippon Ganka Gakkai Zasshi 2009; 113(3): 403-22. [PMID: 19348185]

[243] Satofuka S, Ichihara A, Nagai N, et al. (Pro)renin receptor promotes choroidal neovascularization by activating its signal transduction and tissue renin-angiotensin system. Am J Pathol 2008; 173(6): 1911-8. [http://dx.doi.org/10.2353/ajpath.2008.080457] [PMID: 18974301]

[244] Hikichi T, Mori F, Takamiya A, et al. Inhibitory effect of losartan on laser-induced choroidal neovascularization in rats. Am J Ophthalmol 2001; 132(4): 587-9. 
[http://dx.doi.org/10.1016/S0002-9394(01)01139-4] [PMID: 11589891]

[245] Nagai N, Oike Y, Izumi-Nagai K, et al. Angiotensin II type 1 receptor-mediated inflammation is required for choroidal neovascularization. Arterioscler Thromb Vasc Biol 2006; 26(10): 2252-9. [http://dx.doi.org/10.1161/01.ATV.0000240050.15321.fe] [PMID: 16888236]

[246] Nabah YN, Mateo T, Estellés R, et al. Angiotensin II induces neutrophil accumulation in vivo through generation and release of CXC chemokines. Circulation 2004; 110(23): 3581-6. [http://dx.doi.org/10.1161/01.CIR.0000148824.93600.F3] [PMID: 15569833]

[247] Buschini E, Fea AM, Lavia CA, et al. Recent developments in the management of dry age-related macular degeneration. Clin Ophthalmol 2015; 9: 563-74. [http://dx.doi.org/10.2147/OPTH.S59724] [PMID: 25878491]

[248] Multicenter Trial of Cryotherapy for Retinopathy of Prematurity: ophthalmological outcomes at 10 years. Arch Ophthalmol 2001; 119(8): $1110-8$

[http://dx.doi.org/10.1001/archopht.119.8.1110] [PMID: 11483076]

[249] Lutty GA, Chan-Ling T, Phelps DL, et al. Proceedings of the Third International Symposium on Retinopathy of Prematurity: an update on ROP from the lab to the nursery (November 2003, Anaheim, California). Mol Vis 2006; 12: 532-80. [PMID: 16735995]

[250] Autrata R, Senková K, Holousová M, Krejcírová I, Dolezel Z, Borek I. [Effects of intravitreal pegaptanib or bevacizumab and laser in treatment of threshold retinopathy of prematurity in zone I and posterior zone II--four years results]. Cesk Slov Oftalmol 2012; 68(1): 29-36. [PMID: 22679695]

[251] Beharry KD, Valencia GB, Lazzaro DR, Aranda JV. Pharmacologic interventions for the prevention and treatment of retinopathy of prematurity. Semin Perinatol 2016; 40(3): 189-202. [http://dx.doi.org/10.1053/j.semperi.2015.12.006] [PMID: 26831641]

[252] Yokota H, Nagaoka T, Mori F, et al. Prorenin levels in retinopathy of prematurity. Am J Ophthalmol 2007; 143(3): 531-3. [http://dx.doi.org/10.1016/j.ajo.2006.10.046] [PMID: 17317409]

[253] Moravski CJ, Kelly DJ, Cooper ME, et al. Retinal neovascularization is prevented by blockade of the renin-angiotensin system. Hypertension 2000; 36(6): 1099-104. [http://dx.doi.org/10.1161/01.HYP.36.6.1099] [PMID: 11116132]

[254] Sarlos S, Rizkalla B, Moravski CJ, Cao Z, Cooper ME, Wilkinson-Berka JL. Retinal angiogenesis is mediated by an interaction between the angiotensin type 2 receptor, VEGF, and angiopoietin. Am J Pathol 2003; 163(3): 879-87. [http://dx.doi.org/10.1016/S0002-9440(10)63448-7] [PMID: 12937129]

[255] Downie LE, Pianta MJ, Vingrys AJ, Wilkinson-Berka JL, Fletcher EL. AT1 receptor inhibition prevents astrocyte degeneration and restores vascular growth in oxygen-induced retinopathy. Glia 2008; 56(10): 1076-90. [http://dx.doi.org/10.1002/glia.20680] [PMID: 18442090]

[256] Lonchampt M, Pennel L, Duhault J. Hyperoxia/normoxia-driven retinal angiogenesis in mice: a role for angiotensin II. Invest Ophthalmol Vis Sci $2001 ; 42(2): 429-32$ [PMID: 11157878]

[257] Tadesse M, Yan Y, Yossuck P, Higgins RD. Captopril improves retinal neovascularization via endothelin-1. Invest Ophthalmol Vis Sci 2001; 42(8): 1867-72. [PMID: 11431455]

[258] Otani A, Takagi H, Oh H, et al. Angiotensin II-stimulated vascular endothelial growth factor expression in bovine retinal pericytes. Invest Ophthalmol Vis Sci 2000; 41(5): 1192-9. [PMID: 10752960]

(C) 2017 Holappa et al.

This is an open access article distributed under the terms of the Creative Commons Attribution 4.0 International Public License (CC-BY 4.0), a copy of which is available at: https://creativecommons.org/licenses/by/4.0/legalcode. This license permits unrestricted use, distribution, and reproduction in any medium, provided the original author and source are credited. 